\title{
Analysis of Transcriptome, Selected Intracellular Signaling Pathways, Proliferation and Apoptosis of LNCaP Cells Exposed to High Leptin Concentrations
}

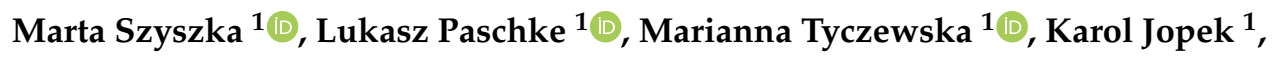 \\ Piotr Celichowski ${ }^{1}$, Paulina Milecka ${ }^{1}$, Gulnara Sultanova ${ }^{2}$, Ewelina Stelcer 1,3,4, \\ Agnieszka Malinska ${ }^{1}$, Ludwik K. Malendowicz ${ }^{1}$ and Marcin Rucinski ${ }^{1, *(D)}$ \\ 1 Department of Histology and Embryology, Poznan University of Medical Sciences, Swiecickiego 6 Street, \\ 60-781 Poznan, Poland; mszyszka@ump.edu.pl (M.S.); paschkelukasz@gmail.com (L.P.); \\ maritycz@ump.edu.pl (M.T.); kjopek@ump.edu.pl (K.J.); pcelichowski@ump.edu.pl (P.C.); \\ paulina.a.grabowska@gmail.com (P.M.); ewelina.stelcer@wco.pl (E.S.); amalinsk@ump.edu.pl (A.M.); \\ lkm@ump.edu.pl (L.K.M.) \\ 2 West Kazakhstan Marat Ospanov Medical University, Maresyev 68 Street, Aktobe 030019, Kazakhstan; \\ stomfak.zkgmu@mail.ru \\ 3 Radiobiology Lab, Greater Poland Cancer Centre, Garbary 15th Street, 61-866 Poznan, Poland \\ 4 Department of Electroradiology, Poznan University of Medical Sciences, Garbary 15th, \\ 61-866 Poznan, Poland \\ * Correspondence: marcinruc@ump.edu.pl; Tel.: +48-61-854-6443
}

Received: 29 September 2019; Accepted: 28 October 2019; Published: 30 October 2019

check for updates

\begin{abstract}
Leptin, the first discovered adipokine, has been connected to various physiological and pathophysiological processes, including cancerogenesis. Increasing evidence confirms its influence on prostate cancer cells. However, studies on the effects of leptin on the proliferation and apoptosis of the androgen-sensitive LNCaP line of prostate cancer cells brought conflicting results. Therefore, we performed studies on the effects of high LEP concentration $\left(1 \times 10^{-6} \mathrm{M}\right)$ on gene expression profile, change of selected signaling pathways, proliferation and apoptosis of LNCaP cells. RTCA (real-time cell analyzer) revealed inhibitory effect of LEP on cell proliferation, but lower LEP concentrations $\left(10^{-8}\right.$ and $\left.10^{-10} \mathrm{M}\right)$ did not affect cell division. Moreover, flow cytometry with a specific antibody for Cleaved PARP-1, an apoptosis marker, confirmed the activation of apoptosis in leptin-exposed LNCaP line of prostate cancer cells. Within $24 \mathrm{~h}$ LEP $\left(10^{-6} \mathrm{M}\right)$ increases expression of 297 genes and decreases expression of 119 genes. Differentially expressed genes (DEGs) were subjected to functional annotation and clusterization using the DAVID bioinformatics tools. Most ontological groups are associated with proliferation and apoptosis (seven groups), immune response (six) and extracellular matrix (two). These results were confirmed by the Gene Set Enrichment Analysis (GSEA). The leptin's effect on apoptosis stimulation was also confirmed using Pathview library. These results were also confirmed by qPCR method. The results of Western Blot analysis (exposure to LEP $10 \mathrm{~min}, 1,2,4$ and $24 \mathrm{~h}$ ) suggest (after $24 \mathrm{~h}$ ) decrease of p38 MAPK, p44-42 mitogen-activated protein kinase and Bcl-2 phosphorylated at threonine 56. Moreover, exposure of LNCaP cells to LEP significantly stimulates the secretion of matrix metallopeptidase 7 (MMP7). Obtained results suggest activation of apoptotic processes in LNCaP cells cultured at high LEP concentration. At the same time, this activation is accompanied by inhibition of proliferation of the tested cells.
\end{abstract}

Keywords: prostate cancer cells; LNCaP; leptin; transcriptome analysis; proliferation; apoptosis; intracellular signaling pathways 


\section{Introduction}

Leptin (LEP) is predominantly produced and secreted by adipose tissue, functioning mainly in the regulation of energy balance and food intake. Due to the fact that LEP and its receptors are widely expressed, LEP is also a multifunctional pleiotropic hormone, acting as an auto, para and endocrine signal. The increasing body of evidence indicates that the influence of LEP extends to several hypothalamic-pituitary-endocrine axes including adrenal, thyroid, pancreatic islands. Moreover, the role of leptin in immune function, haematopoiesis, osteogenesis and angiogenesis was also documented [1]. LEP levels in human blood (LEP normal blood levels are reported to be $1-15 \mathrm{ng} / \mathrm{mL}$ ) increase in several diseases, including metabolic disorders leading to obesity. Hyperleptinemia is also associated with the pathogenesis of some cancer types. [2-7]. It was shown that elevated serum and tissue LEP level is involved in the pathogenesis of lung cancer and tumor metastasis [8]. Hyperleptinemia is also associated with metastases of melanoma to lymph nodes [9] and is considered as pathophysiological factor in pathogenesis of breast cancer [10]. In the literature, there are also several reports about the role of LEP in the progression of prostate cancer [11-16].

Earlier studies on rats identified various isoforms of the LEP receptor in the rat prostate and seminal vesicles and suggested that this cytokine exerts a stimulating effect on the proliferation of epithelial cells of these organs [17-20]. However, data on LEP receptor expression in human prostate are very scarce. Cioffi et al. identified different variants of the LEP receptor (LEPR) using the Northern blot method in human prostate tissue [21]. In other studies, using RT-PCR method, the following LEPR variants were expressed in tissue samples from benign prostatic hyperplasia (BPH): variants 4 and 2 (in all five samples studied), var. 5 (3/5) and var. 6 and 3 (4/5) [22]. Moreover, Leze et al. demonstrated that incubation of human hyperplastic prostate tissue fragments with LEP $(50 \mathrm{ng} / \mathrm{mL})$ for $3 \mathrm{~h}$ significantly stimulates proliferation of epithelial cells and expression of pro-apoptotic $B A X$ gene [23].

Difficulties in acquiring appropriate prostate fragments have led various research groups to perform research on various human normal prostate and prostate cancer cell lines. However, the expression of different variants of LEPR in these cells differs significantly [24]. There are also differences in the results of research on the role of LEP in the regulation of proliferation and apoptosis of these cell lines. In the case of LNCaP cells LEP either does not change the proliferation rate of these cells [24-26], may stimulate it $[27,28]$, and at high concentrations of the cytokine tested $\left(1 \times 10^{-6} \mathrm{M}\right)$ may inhibit the growth of these cells [24]. Taking into account the latter finding, it should be stressed that in comparable concentrations of LEP $(12.5 \mu \mathrm{g} / \mathrm{mL})$ no proliferation changes were observed in LNCaP cells [25], whereas in DU145 cells this concentration of cytokine stimulated proliferation of studied cells [29].

Considering the abovementioned discrepancies, we decided to analyze the effect of high concentrations of LEP on proliferation, gene expression profile and changes in selected signaling pathways of LNCaP cells.

\section{Results}

\subsection{Leptin at a Dose of $1 \times 10^{-6} \mathrm{M}$ Exerted an Inhibitory Effect on Proliferative Activity of LNCaP Cells and Stimulate Apoptosis}

Using a real-time proliferation assay, we examined the effect of LEP, at concentrations of $10^{-6}$, $10^{-8}$, and $10^{-10} \mathrm{M}$, on the proliferation rate of LNCaP cells. As we shown in Figure 1A, LEP at a dose of $1 \times 10^{-6} \mathrm{M}$ leads to a significant inhibition of LNCaP cells proliferation. Both lower LEP concentrations $\left(10^{-8}, 10^{-10} \mathrm{M}\right)$ did not affect the proliferation rate of cultured cells. Therefore, further studies were performed with LEP at a dose of $1 \times 10^{-6} \mathrm{M}$ in relation to the control group. Based on median fluorescence intensity, LNCaP cells treated with the highest LEP concentration $\left(1 \times 10^{-6} \mathrm{M}\right)$ revealed $30 \%$ higher level of apoptosis in comparison with untreated cells (control) (Figure 1B). In LNCaP cells treated with lower concentrations of leptin $\left(10^{-8}\right.$ and $\left.10^{-10} \mathrm{M}\right)$ we did not observed statistically significantly differences (data not shown). 

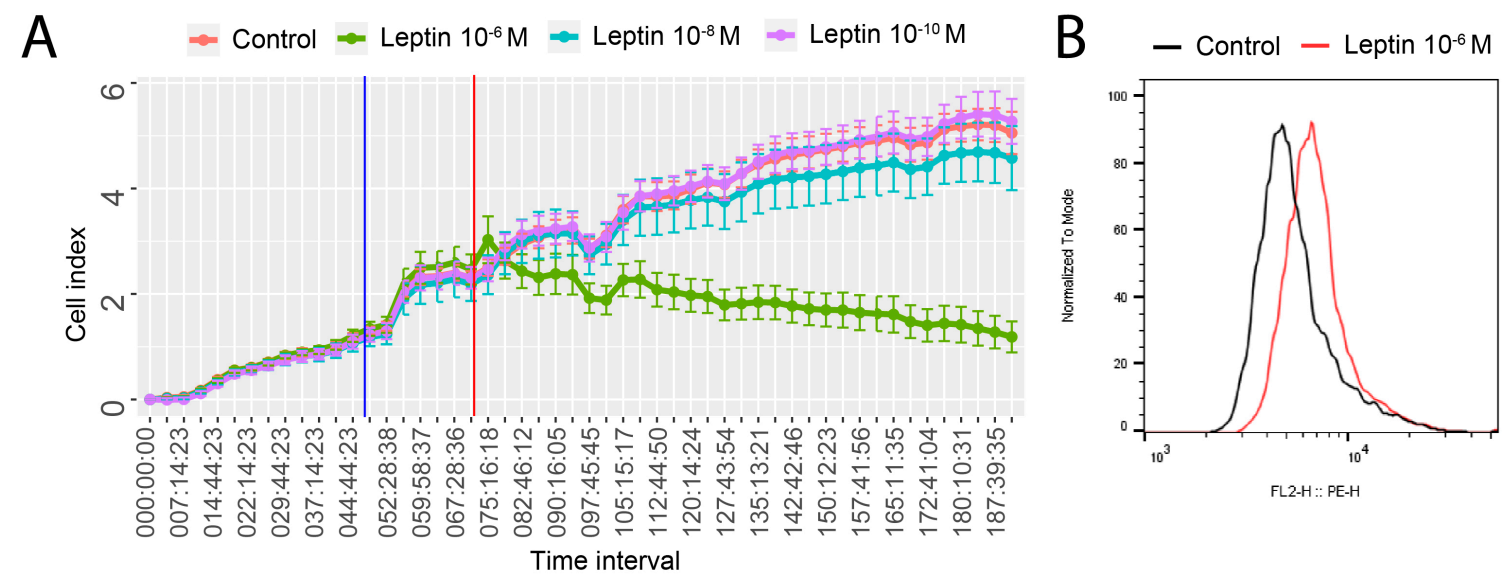

Figure 1. (A) Cell index values of LNCaP cells cultivated for $196 \mathrm{~h}$ in the presence of various LEP concentrations. Electrical impedance is measured throughout the cultivation period at a 15-minutes frequency. The time point of the medium changed to starvation medium is marked with a blue vertical line. LEP is provided at the time point indicated by a red vertical line. The mean cell index values with SE for the eight repetitions in each group are shown. (B) Flow cytometry analysis of Cleaved PARP-1. Median fluorescence intensity, LNCaP cells treated with LEP $\left(1 \times 10^{-6} \mathrm{M}\right)$ in relation to untreated control group.

\subsection{Leptin at a Dose of $1 \times 10^{-6} \mathrm{M}$ Significantly Modulates the Transcriptomic Profile of LNCaP Cells}

The GeneChip Human Genome U219 Array Strips used in the current study allowed the simultaneous examination of the gene expression of 19,285 human transcripts. The transcriptome study was performed $24 \mathrm{~h}$ after LEP administration $\left(1 \times 10^{-6} \mathrm{M}\right)$ to the culture medium. The transcriptome profile was compared with the untreated (control) group. The general profile of transcriptome changes was shown as a volcano plot (Figure 2A).
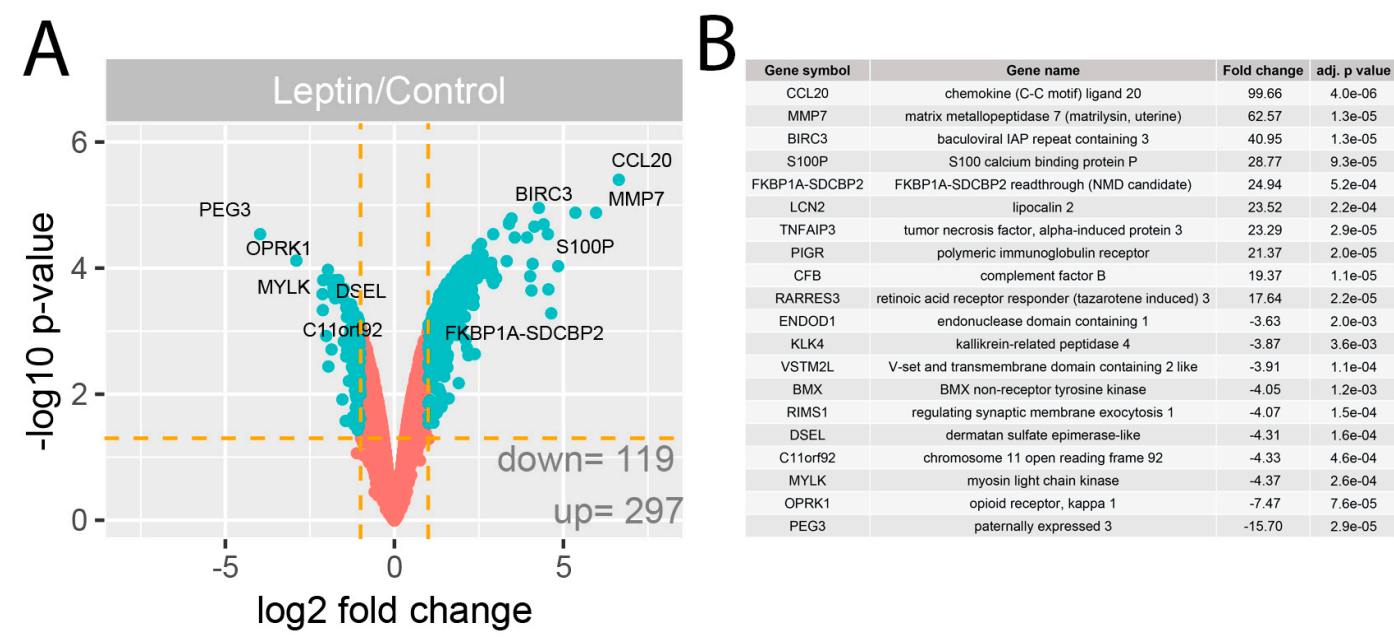

Figure 2. (A) Volcano plots of total gene expression profiles of the LNCaP prostate cell line after $24 \mathrm{~h}$ incubation with LEP $\left(1 \times 10^{-6} \mathrm{M}\right)$. Each dot represents the mean expression $(n=2)$ of the individual gene obtained from a microarray normalized dataset. The orange dotted lines (cut off values) were established according to the following parameters: fold $=|2|$ and $p$-value with FDR correction $=5 \%$. Genes above the cut-off lines have been considered as differentially expressed genes (DEG) and are shown as turquoise dots. The total numbers of DEG are presented in the bottom right corner of the graph. Ten the most regulated genes are marked by their gene symbols. (B) List of 20 genes with the highest (10 genes) and lowest (10 genes) fold changes obtained from the datasets of differentially expressed genes. 
We assumed the following selection criteria for differentially expressed genes (DEG): an expression fold difference $>$ absolute 2 and an adjusted $p$-value $\leq 0.05$. According to these criteria, 297 genes were up-regulated, while 119 were down-regulated as consequence of LEP action. The ten genes with the highest and lowest fold change values are presented in tabular format displaying the gene symbol, gene name, fold change and adjusted $p$-value (Figure 2B). These genes were characterised by high fold change values, especially for up-regulated genes (fold range for up-regulated genes: 99.66-17.64, and for down-regulated genes: $-15.70--3.63)$. Among others these genes include: chemokine (C-C motif) ligand $20($ CCL20, fold $=99.66)$, matrix metallopeptidase $7(\mathrm{MMP7}$, fold $=62.57)$, tumor necrosis factor, alpha-induced protein (TNFAIP3, fold $=23.29$ ).

2.3. LEP at $1 \times 10^{-6} M$ Concentration Exerts a Significant Effect on the Genes Involved in the Regulation of the Following Biological Processes: Apoptosis, Immunological Response and Extracellular Matrix Organisation

To determine which biological processes can be regulated by LEP, we performed an analysis of the enrichment in the relevant ontological groups from the GO BP Direct database. A whole set of differentially expressed genes (DEGs) consisting of 416 genes (297 up- and 119 down-regulated) was subjected to functional annotation and clusterization using the Database for Annotation, Visualization, and Integrated Discovery (DAVID) bioinformatics tools. The result of this analysis was shown as a bubble plot (Figure 3) where we presented only ontological groups fulfilling the following criteria: adjusted $p$-values below 0.05 and minimal number of genes per group $>10$.

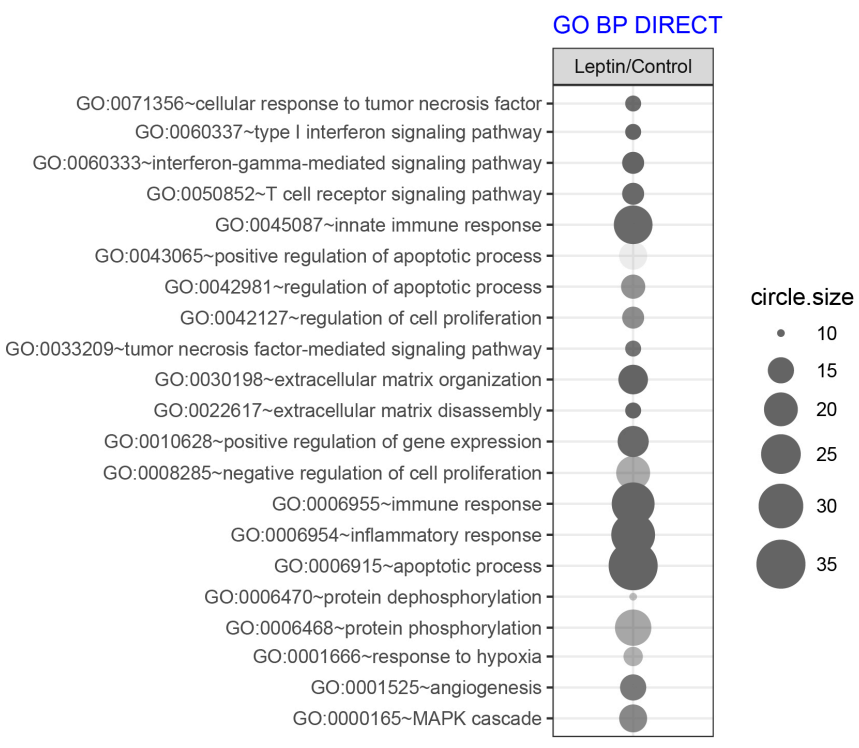

Figure 3. Bubble plot of overrepresented gene sets in DAVID GO BP DIRECT annotations database obtained from comparisons in gene expression profiles between LEP-treated LNCaP vs. control. The graph show only the GO groups above the established cut-off criteria ( $p$ with correction $<0.05$, a'minimal number of genes per group $>10$ ). The size of each bubble reflects the number of differentially expressed genes, assigned to the GO BP terms. Transparency of the bubbles displays $p$-value (more transparent-closer to the border of $p=0.05)$.

The performed analysis revealed 21 ontological groups. The majority of them involved: regulation of proliferation and apoptosis $(n=7)$, imunological response $(n=6)$ and organization of extracellular matrix $(n=2)$, signaling of MAPK $(n=1)$. The detailed characteristics of the above mentioned ontological groups were as follows: "GO:0071356 cellular response to tumor necrosis factor" ( $\mathrm{n}=11$, adj. $p$ value $=0.02)$, "GO:0043065 positive regulation of apoptotic process" $(\mathrm{n}=16$, adj. $p$ value $=0.04)$, “GO:0042981 regulation of apoptotic process" $(\mathrm{n}=14$, adj. $p$ value $=$ 0.03), "GO:0042127 regulation of cell proliferation" ( $\mathrm{n}=12$, adj. $p$ value $=0.03$ ), “GO:0033209 tumor necrosis factor-mediated signaling pathway" $(\mathrm{n}=11$, adj. $p$ value $=0.02)$, “GO:0008285 negative 
regulation of cell proliferation" $(\mathrm{n}=20$, adj. $p$ value $=0.026)$, "GO:0006915 apoptotic process" $\left(\mathrm{n}=35\right.$, adj. $p$ value $\left.=1.30 \times 10^{-4}\right)$, "GO:0060337 type I interferon signaling pathway" ( $\mathrm{n}=11$, adj. $p$ value $=5.03 \times 10^{-4}$, "GO:0060333 interferon-gamma-mediated signaling pathway" ( $\mathrm{n}=13$, adj. $p$ value $\left.=6.41 \times 10^{-5}\right)$, "GO:0050852 $\mathrm{T}$ cell receptor signaling pathway" $(\mathrm{n}=13$, adj. $p$ value $=$ 0.02), “GO:0045087 innate immune response" ( $\mathrm{n}=24$, adj. $p$ value $=0.02)$, “GO:0006955 immune response" $\left(\mathrm{n}=28\right.$, adj. $p$ value $\left.=5.32 \times 10^{-4}\right)$, "GO:0006954 inflammatory response" $(\mathrm{n}=29$, adj. $p$ value $\left.=9.12 \times 10^{-5}\right)$, "GO:0030198 extracellular matrix organization" $(\mathrm{n}=17$, adj. $p$ value $=$ $\left.2.03 \times 10^{-3}\right)$, “GO:0022617 extracellular matrix disassembly" $\left(\mathrm{n}=11\right.$, adj. $p$ value $\left.=1.94 \times 10^{-4}\right)$, "GO:0000165 MAPK cascade" ( $\mathrm{n}=16$, adj. $p$ value $=0.03$ ).

The above results were confirmed by another powerful bioinformatic tool-Gene Set Enrichment Analysis (GSEA). In this analysis, the fold change values of all genes were $\log 2$ transformed and ranked according their $\log F C$. Afterwards, these values were used for a 1000 times permutation test to calculate the enrichment score (ES) within predefined gene sets from the Hallmark database. Enrichment scores were normalized regarding gene set size and presented as normalised enrichment score (NES). The result of the GSEA analysis for the ranked log2 fold change values of LEP $\left(1 \times 10^{-6} \mathrm{M}\right)$ vs. control group was presented in Figure 4. The ten hallmark database groups with the highest absolute NES value were presented in Figure 4A. Within the gene ranks column each vertical line represents one gene and its position depends on the $\log \mathrm{FC}$ value (around 0 are genes with high $\log \mathrm{FC}$ value on which LEP had a stimulating effect-enriched genes, on the right side around 19,285-there are genes whose expression due to LEP action is lowered and had a low logFC value-depleted genes). Despite a different methodological approach, the GSEA analysis presents relatively similar groups as shown in the analysis of ontological groups by DAVID. This groups concern: apoptosis/proliferation and immunological processes. The analysis regarding the position of single genes on gene rank scale and consequently the NES values of individual groups indicates that LEP stimulates expression of genes in the immune response hallmark group. Genes involved in the regulation of apoptosis are also strongly stimulated by LEP. The analysis of enrichment within the Hallmark apoptosis group is characterized by a high positive value of NES $=4.25$ and includes genes with a very high $\log F C$ value as it is shown in Figure 4C. Interestingly, the GSEA analysis also showed a significant decrease in expression of genes closely related to proliferation belonging to the following sets of hallmark database "mitotic spindle" (NES = -2.92) and "G2M checkpoint". (NES = -4.79). These groups are composed of the genes with very low $\log F C$ values and therefore their expression is suppressed by LEP (Figure 4C).
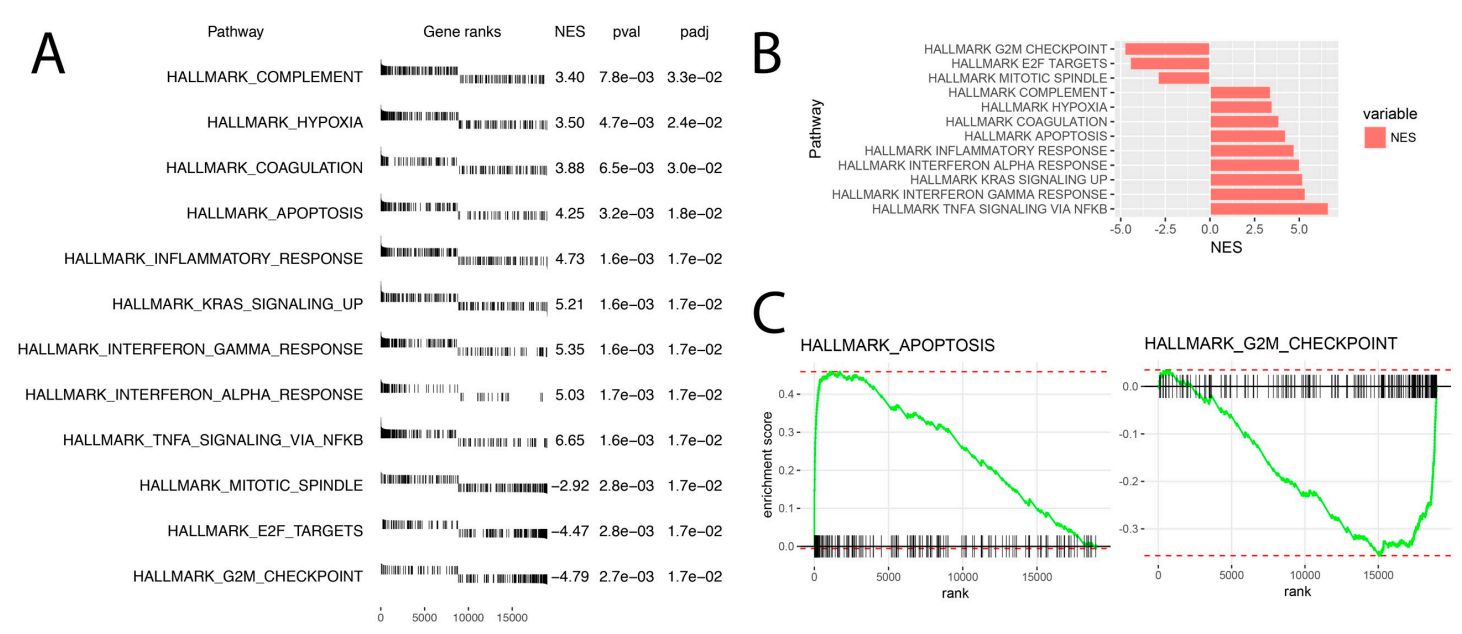

Figure 4. Gene set enrichment analysis using Hallmark gene sets. (A) List of significantly enrichment gene sets with appropriate gene ranks, normalized enrichment score (NES), $p$ values (pval) and $p$ values after FDR correction (padj). (B) Bar chart of normalized enrichment score (NES) values for previously selected gene sets. (C) Enrichment plot of "Hallmark apoptosis" and "Hallmark G2M checkpoint" gene sets. 


\subsection{Detailed Analysis of the LEP-Regulated Gene Expression in LNCaP Cells}

Because DAVID and GSEA analyses indicated potent regulation by LEP of genes related to proliferation/apoptosis, as well as due to a significant decrease in proliferation under the influence of LEP in RTCA study, in the next step we analysed specific genes belonging to the following ontological groups: "apoptotic process", "regulation of cell proliferation", "regulation of apoptotic process", "negative regulation of cell proliferation", "positive regulation of apoptotic process". The fold change values of genes forming the mentioned groups were used to calculate Z-score which indicates whether the process decreased (negative value) or increased (positive value) and presented as circular scatter plots. Z-score was calculated automatically using the GOplot library. Despite the presence of several expression decreased genes, all of the analysed ontological groups were characterised by a positive value of $Z$-score, confirming the stimulating effect exerted by LEP on the given processes. (Figure 5A). Due to ambiguous nature of the gene ontology structure, single genes can often be assigned to many ontological terms. For this reason, the relationship between genes and GO terms were mapped with circos plots with visualization of $\log \mathrm{FC}$ values and gene symbols (Figure 5B). The strongest up-regulated genes from the examined ontological groups included, among others: BIRC3-baculoviral IAP repeat containing 3, FAS-Fas cell surface death receptor, TNFAIP3-tumor necrosis factor, alpha-induced protein 3, TNF-tumor necrosis factor, GADD45G—growth arrest and DNA-damage-inducible protein GADD45 gamma.
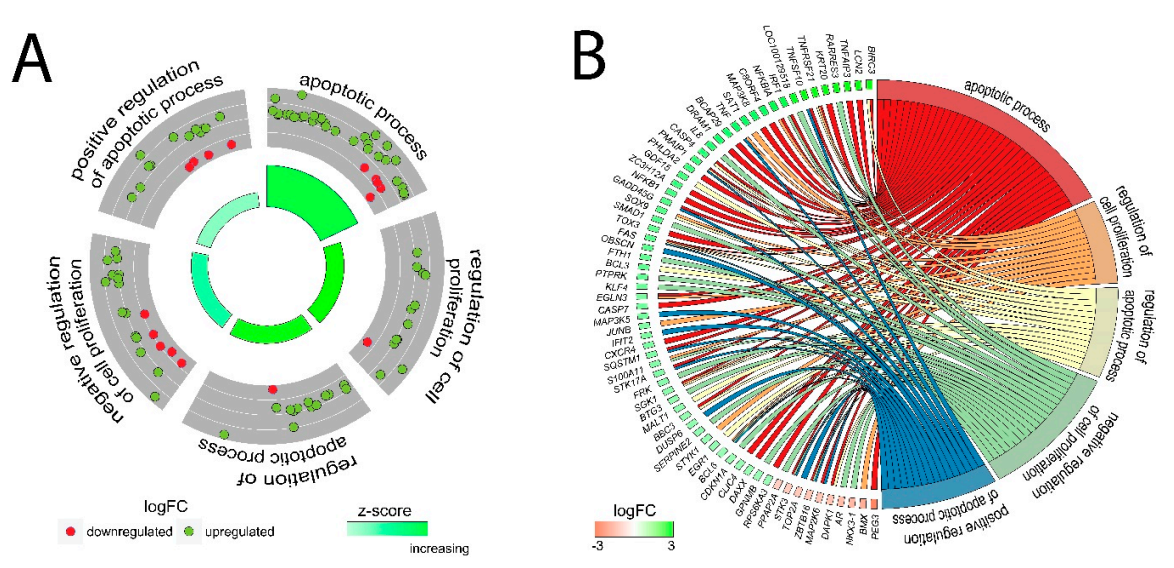

Figure 5. Detailed analysis of five enriched gene ontological groups involved in proliferation/apoptosis. (A) The circular scatter plots of differentially expressed genes involved in specific GO terms (positive regulation of apoptotic process, apoptotic process, regulation of cell proliferation, regulation of apoptotic process, negative regulation of cell proliferation). Each dot represents a single gene whose expression is increased (green) or decreased (red) due to LEP action. Positive value of Z-score mapped on a red colour scale was presented inside the graph. (B) Circos plots with interdependence between selected GO terms and their genes. Symbols of DEG are presented on the left side of the graph with their fold change values, mapped by colour scale (green = higher expression; red = lower expression). Gene involvement in the GO terms was determined by coloured connecting lines.

The leptin's effect on apoptosis stimulation was also confirmed using Pathview library. Fold values of DEGs were mapped with appropriate colours for each gene forming "Apoptosis" (Figure 6) and "p53 signaling pathway" (Figure 7). Green colour indicates statistically significant gene up-regulation and red colour refers to down-regulated genes. Grey colour marked genes whose expression was not significantly changed. Analogous to the David analysis with circosplot visualization, most of the genes displayed in "Apoptosis" and "p53 signaling pathway" were up-regulated. This result confirms the stimulatory effect of LEP on apoptosis activation, moreover, it is consistent with the previously described LEP effect causing a decrease in LNCaP cells proliferation. 


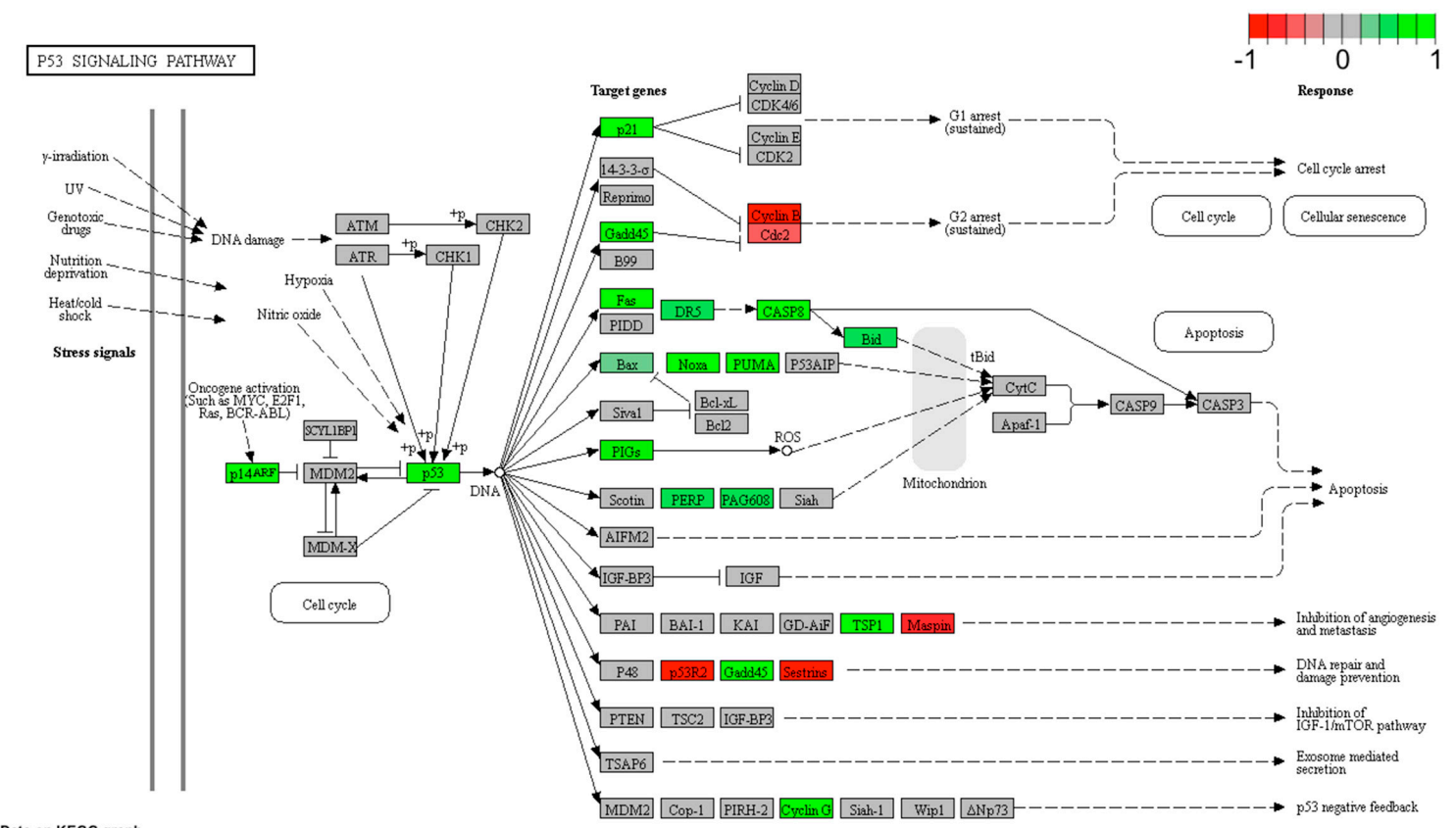

Data on KEGG graph
Rendered by Pathview

Figure 6. p53 signaling pathway in LNCaP cells treated with LEP $\left(1 \times 10^{-6} \mathrm{M}\right)$. Expression changes of target genes are mapped by colours; green colour-statistically significant increase in expression, red colour—statistically significant decrease in expression, grey colour—statistically insignificant.

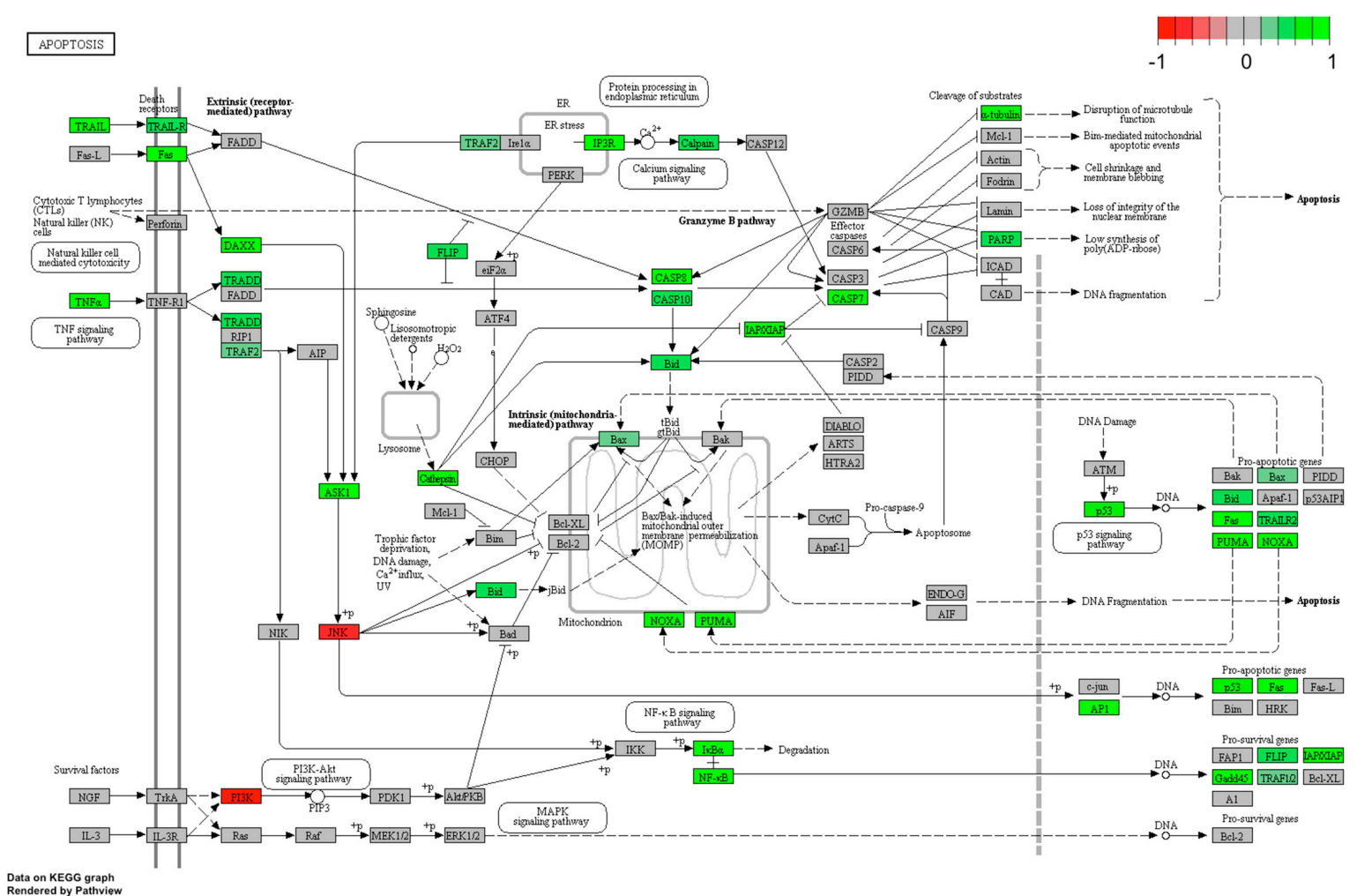

Figure 7. Apoptosis pathway in LNCaP cells treated with LEP $\left(1 \times 10^{-6} \mathrm{M}\right)$. Expression changes of target genes are mapped by colours; green colour-statistically significant increase in expression, red colour-statistically significant decrease in expression, grey colour-expression statistically insignificant. 
The expression of several differentially expressed genes was also validated using qPCR. Significantly different genes were selected for validation according to the Volcano Plot and the list of genes with the largest fold changes obtained from the datasets with differentially expressed genes (Figure 2A,B). Our findings confirmed the effect exerted by LEP on the expression of examined genes, namely: $B M X-B M X$ non-receptor tyrosine kinase, C11orf92—chromosome 11 open reading frame 92, KLK4-kallikrein-related peptidase 4, MYLK—-myosin light chain kinase, RIMS1—regulating synaptic membrane exocytosis 1, BIRC3-baculoviral IAP repeat containing, FAS-apoptosis signal receptor/cell surface death receptor, $M M P 7$-matrix metallopeptidase 7, TNFAIP3-tumor necrosis factor, alpha-induced protein 3 . In accordance with the results from microarrays, the expression of all the above-mentioned genes was stimulated by LEP at $1 \times 10^{-6} \mathrm{M}$ concentration (Figure 8).
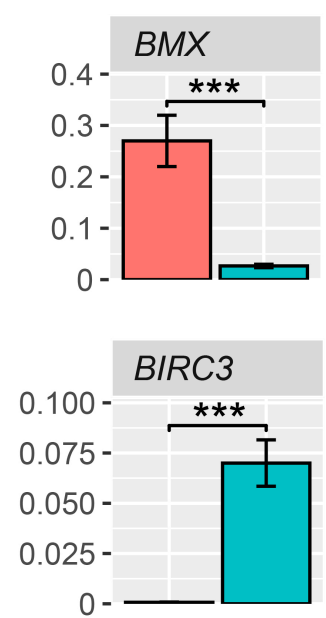
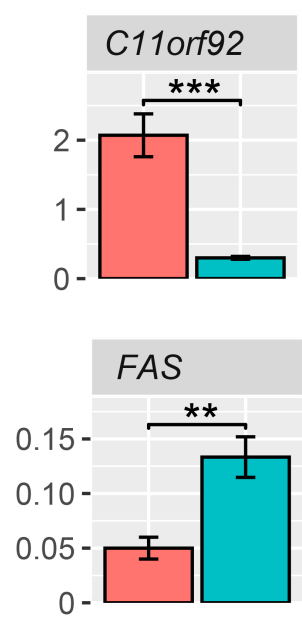
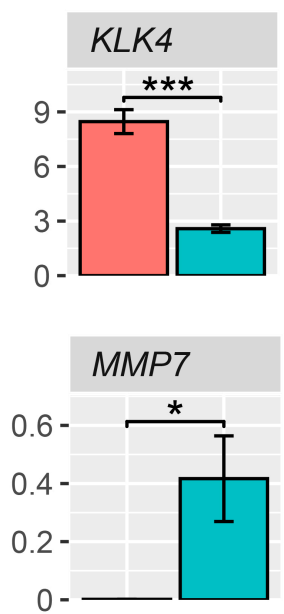
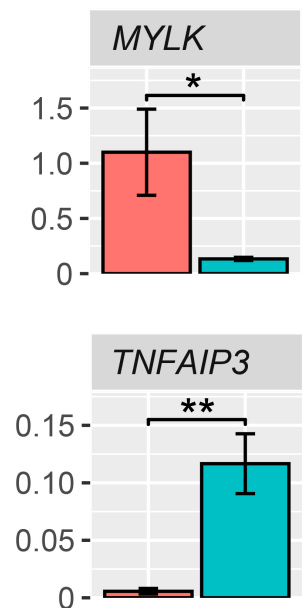
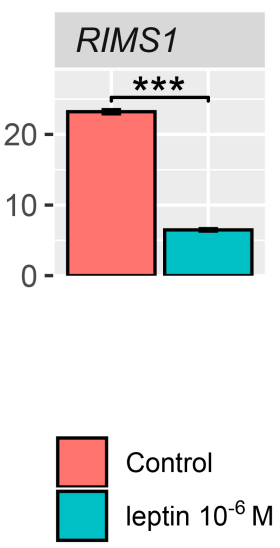

Figure 8. Real time $\mathrm{qPCR}$ validation of microarray data. $B M X-\mathrm{BMX}$ non-receptor tyrosine kinase, C11orf92 - chromosome 11 open reading frame 92, KLK4-kallikrein-related peptidase 4, MYLK-myosin light chain kinase, RIMS1-regulating synaptic membrane exocytosis 1, $B I R C 3$ - baculoviral IAP repeat containing, FAS—apoptosis signal receptor/cell surface death receptor, MMP7-matrix metallopeptidase 7, TNFAIP3-tumor necrosis factor, alpha-induced protein 3. Results are presented as means $\pm \mathrm{SEM}, n=3$. Statistical comparison by Student's t-test: ${ }^{*} p<0.05$; ** $p<0.02 ;{ }^{* * *} p<0.01$.

\subsection{LEP Regulates Several Key Factors of Signaling Pathways Involved in Apoptosis,} Proliferation and Migration

In the next step, we studied the contribution of LEP in modulation of several important signaling pathways involved in apoptosis/proliferation regulation. The study was carried out through the incubation of LNCaP cells with LEP in the following time series: 0 min (control), $10 \mathrm{~min}, 1 \mathrm{~h}, 2 \mathrm{~h}, 4 \mathrm{~h}$ and $24 \mathrm{~h}$. Obtained results were compared to the control group. Activation of signaling pathways was analyzed using antibodies directed to p38 mitogen-activated protein kinase, p44-42 mitogen-activated protein kinase, Bcl-2 phosphorylated at threonine 56 and total Stat1. Densitometric analysis was normalized in relation to GAPDH levels and presented in Figure 9. Up to the 2nd hour of culture in the presence of LEP we did not find its effect on p38 mitogen-activated protein kinase, while from the 4th to the 24th hour we observed a significant decrease in p38 MAPK activation. During the studied time interval, p44-42 mitogen-activated protein kinase was consistently decreased and achieved a statistically significant reduction by the 24th $\mathrm{h}$. Bcl-2 phosphorylated at threonine 56 increased rapidly at $10 \mathrm{~min}$ of incubation. This increase was maintained until the 2 nd hour of culture. From the fourth hour, it was significantly lowered and this reduction was also maintained at the 24th hour. Stat1 expression was relatively stable up to the 2nd hour and then gradually increased to reach a statistically significant value at $24 \mathrm{~h}$ of culture. 

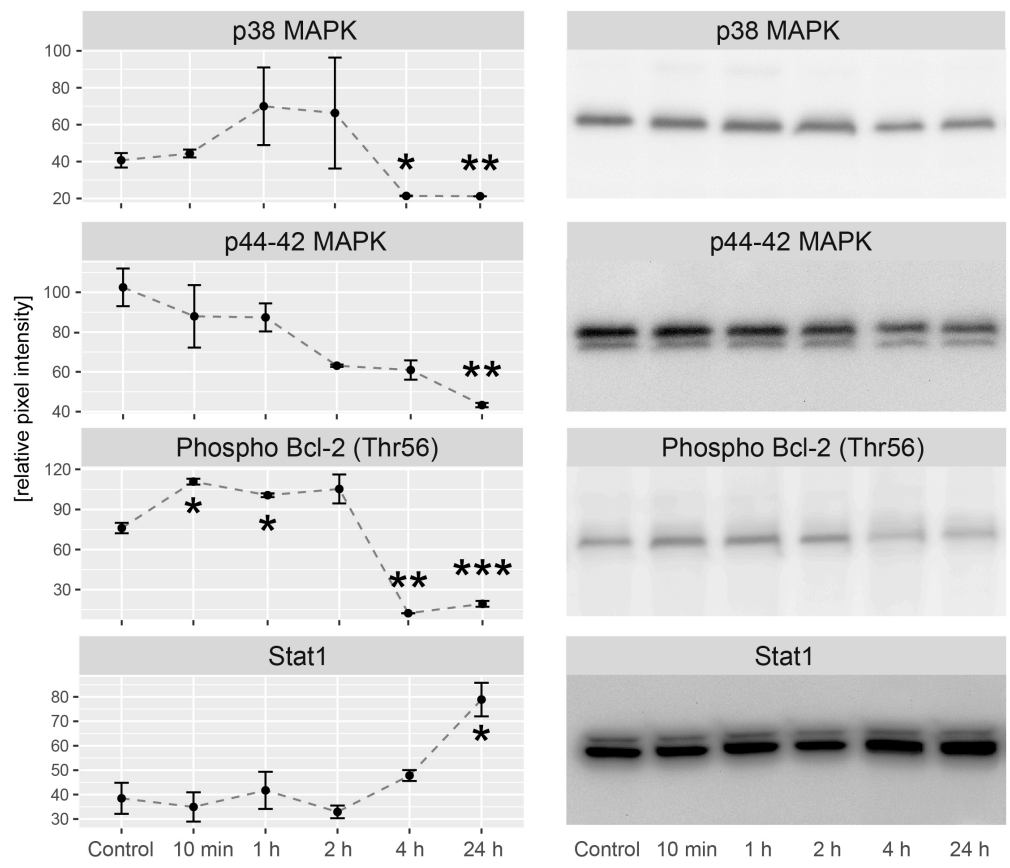

Figure 9. Densitometric analysis includes several key factors of signaling pathways involved in apoptosis, proliferation in different time after the treatment with LEP. Graphs represent protein expression relative to glyceraldehyde-3-phosphate dehydrogenase (GAPDH) levels. Representative experiments of proteins immunoblotting were also shown. Results are presented as means \pm SEM, $n=3$. Statistical comparison by Student's t-test: ${ }^{*} p<0.05,{ }^{* *} p<0.01,{ }^{* * *} p<0.001$.

Matrix metallopeptidase 7-MMP7, was one of the genes whose expression was strongly stimulated by LEP, therefore, we decided to check whether the increase of its expression was also reflected in the protein level. For this purpose, the level of the secreted MMP7 was determined in cell culture medium using ELISA method. As we have shown in Figure 10, LEP significantly stimulates the secretion of MMP7, that was in line with the previously described microarray data (Figure 2A,B) and real-time qPCR validation (Figure 8).

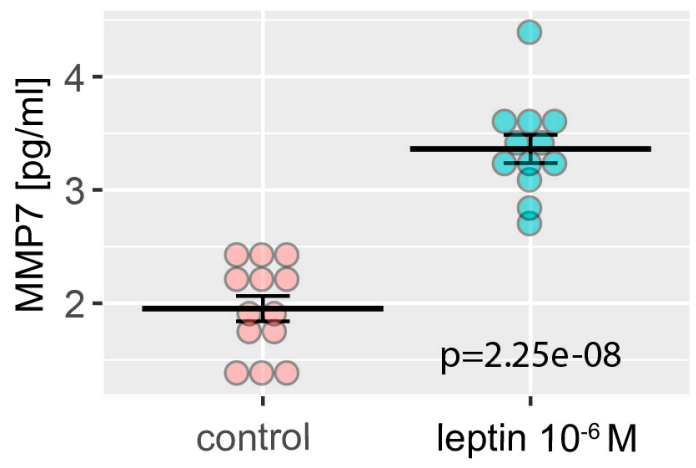

Figure 10. Level of MMP7 in LNCaP cells medium with (blue) or without (red) LEP at $1 \times 10^{-6}$ $\mathrm{M}$ concentration. Levels of MMP7 were measured by ELISA, $n=12\left(10^{-6} \mathrm{M}\right)$ and $n=13$ (control). Results are presented as means \pm SEM. Each dot represents an individual sample. Statistical comparison by Student's t-test: $p$ value shown on the graph. 
2.6. Leptin (LEP), Leptin Receptor (LEPR) and Its Main Downstream Signaling Genes (JAK2, STAT3) Are Downregulated in Prostate Adrenocarcinoma

Analysis of RNAseq data for 52 normal prostate (control) and 498 prostate adenocarcinoma obtained from TCGA database, revealed that LEP, LEPR, JAK2 and STAT3 are statistically significant downregulated in prostate tumors in relation to normal (control) prostate (Figure 11).
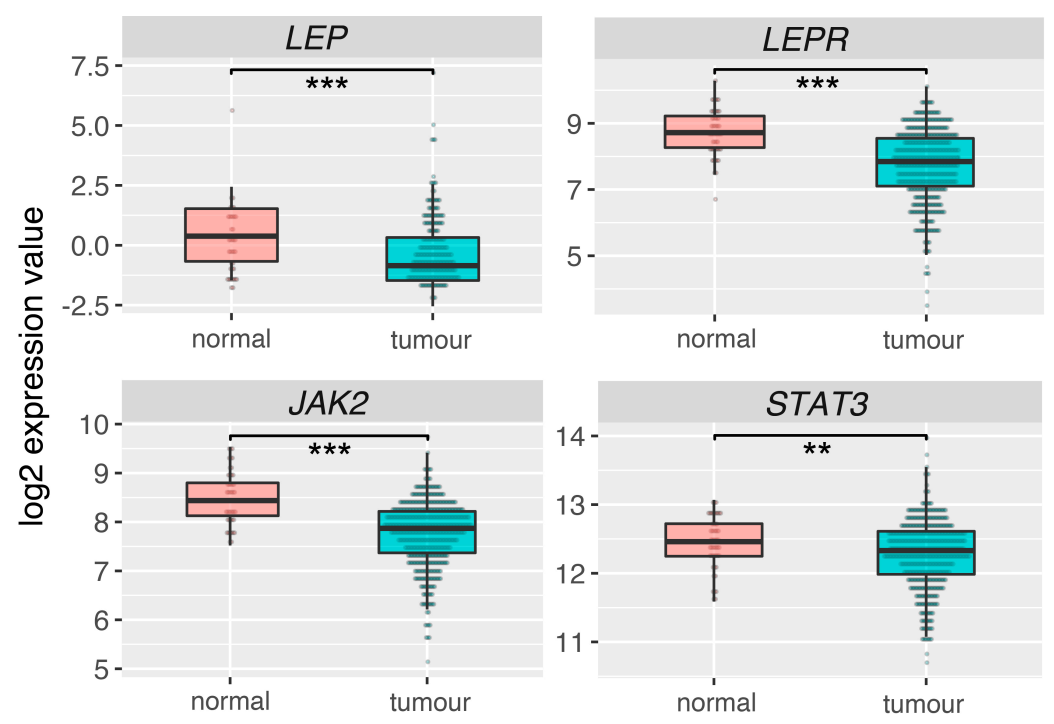

Figure 11. Expression of leptin $(L E P)$, leptin receptor $(L E P R)$ and its main downstream signaling genes (JAK2, STAT3) in normal prostate and adenocarcinoma. Analysis based on data from The Cancer Genome Atlas (TCGA). Results are presented as medians with IQRs. Statistical comparison by Mann-Whitney test: ${ }^{* *} p<0.02 ;{ }^{* *} p<0.01$.

\section{Discussion}

It is generally accepted that LEP affects tumor cell invasion and progression [30,31]. LEP exerts its physiological effect by binding to set of LEP receptors, extended class I cytokine receptor family, composed of six isoforms [32]. Molecular mechanism of LEP action is well described. LEP binding to all short LEP receptors (LEPR var 2-6) leads to activation of Janus-activated kinase (JAK2) with subsequent phosphorylation of insulin receptor substrates (IRS), initiating activation of the phosphoinositide 3 kinase (PI3K)/Akt pathway [29]. Activation of IRS causes also stimulation of NF-kB signaling pathways involved in cell migration and inflammatory response [33]. The long form of the receptor (LEPR var 1) contains an additional intracellular carboxy terminal motif necessary to activate STAT3 and STAT5 [34].

Recently, using multiple sets of specific primers, we have shown that only the second isoform of the LEP receptor is expressed in the LNCaP cell line [24]. Therefore, it seems that the response of LNCaP cells to LEP is mediated via JAK2 kinase activation of LEPR var 2. Moreover, the results of other studies show that STAT3 activation under the influence of LEP in LNCaP cells may occur, however only in cells transiently co-transfected with LEPR var 1 [35]. With regard to this, Deo et al. (2008) revealed that STAT3 of LEP-exposed LNCaP cells undergoes fast dose-depended phosphorylation. This finding indirectly confirms the presence of an active LEPR form in LNCaP cells [27].

The molecular mechanism exerted by LEP was determined using high-throughput microarray, real time PCR, Western Blot and ELISA methods. The use of U219 Array Strips allowed simultaneous examination of transcriptome profile by measurement of 19,285 human genes. In the present study, we identified 416 LEP-responsive genes, most of which were up-regulated (297 genes). The analysis of GO terms including DEGs, revealed that LEP participates in the regulation of apoptosis, immunological response and extracellular matrix organisation in LNCaP cells. Interestingly, a significant number of genes with the highest expression level is related to immunological responses. 
Currently, no available data indicates role of LEP in the regulation of immunological processes in prostate LNCaP cell line, however several arguments support our findings. Both molecular structure of LEP and its receptor allow to include them to the cytokine family. The secondary structure of LEP is similar to the long-chain helical cytokines family, including interleukin 6 (IL-6), IL-11, CNTF and LIF. LEP receptor amino acid sequence shares a strong homology with gp-103 signal-transducing subunit of the IL-6-type cytokine receptors [36]. It was also shown that exogenous LEP causes up-regulation of pro-inflammatory cytokines in macrophages and lymphocytes $\mathrm{T}[37,38]$. There are also reports indicating that the LNCaP cell line is responsive to TNF-alpha, a known pro-inflammatory signal [39]. By means of transcriptome analysis authors revealed the stimulation of pro-inflammatory processes in these cells. In line with our results, this team observed inhibition of proliferation in LNCaP cell exposed to TNF-alpha, and the associated gene expression changes are similar to those observed in our experiments.

Interestingly, the results of our study have also shown that LEP significantly stimulates expression of NF- $\mathrm{KB}$ family members genes: nuclear factor of kappa light polypeptide gene enhancer in B-cells 1 (NFKB1, fold $=3.22, p=0.0001)$, nuclear factor of kappa light polypeptide gene enhancer in B-cells $2(N F K B 2$, fold $=1.6, p=0.005)$, v-rel reticuloendotheliosis viral oncogene homolog $\mathrm{B}$ $(R E L B$, fold $=3.33, p=0.0005)$, v-rel reticuloendotheliosis viral oncogene homolog $(R E L$, fold $=1.57$, $p=0.01$ ). Nuclear factor kappa B (NF-kB) belongs to essential class of transcriptional regulators. NF-KB plays an important role in regulation of multiple physiological processes, among others: the immune response, migration and invasion of cancer cells $[33,40,41]$. Jin et al. (2008) demonstrated that neuropeptides secreted from prostate neuroendocrine cells may activate the NF- $\mathrm{kB}$ pathway in LNCaP prostate cell line [40]. In Du145, PC3 and LNCaP cell lines, LEP induces cell migration through NF-KB [33]. The results of our research seem to confirm the contribution of LEP in the regulation of NF-KB pathway in LNCaP cells, modulating inflammatory processes and cell migration through this signaling pathway.

In the group of genes related to pro-inflammatory response, the highest differences in expression after LEP treatment, was observed in the CCL20 gene. C-C motif chemokine ligand 20 (CCL20) belongs to the subfamily of small chemokine C-C genes involved in inflammatory process. CCL20 is also overexpressed in many types of cancers, however its role in tumors is not fully explained. In the context of prostate cell lines, Beider et al. showed that basal mRNA of CCL20 was detectable in PC3, Du154 cells and presented at very low level in LNCaP cells [42]. Moreover, CCL20 expression in the LNCaP line is stimulated by interleukin-17A [43].

Our results also revealed a significant contribution of LEP to the regulation of extracellular matrix organization. Matrix metalloproteinase 7 (MMP7) plays essential role in prostate cancer cell invasion and epithelial to mesenchymal transition by breaking down extracellular matrix of tumor cells [44]. In this context Zhang et al. (2016), showed that overexpression of MMP7 in LNCaP cells leads to disruption of E-cadherin/ $\beta$-catenin complex and releases $\beta$-catenin, thus enhancing EMT and tumor cell invasion [44]. It is astonishing that MMP7 is not expressed in a normal prostate, whereas is overexpressed in human prostate cancer $[45,46]$. Relatively high expression of MMP7 was observed in our LNCaP cells. MMP7 expression at mRNA and protein level, measured as secretion to cell culture medium, was significantly stimulated by LEP. MMP7 may also play role in apoptosis induction. MMP7 leads to release of membrane bound FASL that induces apoptosis of neighboring cells via death receptor FAS [47-49].

Lipocalin 2 (Lcn2) is described as ligand for matrix metallorproteinase 9, also known as neutrophil gelatinase-associated lipocalin (NGAL). Lcn2 is upregulated in several types of cancers, and has been shown to facilitate tumor progression [50]. In LNCaP cells, Lcn2 upregulation undergoes via NF- kB-dependent manner [51]. In relation to the prostate cancer cell lines there are data proving the contribution of Lcn2 in prostate cell proliferation, however, this effect is dependent on the prostate cell type. Tung et al. (2013) found that LCN2 knock-down in PC3 and DU145, reduced cell growth, 
by induction of cell-cycle arrest at G0/G1 phase and Lcn2 overexpression stimulates growth, migration and invasiveness of $22 \mathrm{Rv}$ cells [50].

Increasing evidence suggests that LEP exerts a significant effect on the proliferation and apoptosis rates of different prostate cell lines, but the results of individual studies are inconclusive. The analysis of the collected data presented in Table 1 indicates that the effect of leptin on proliferation and apoptosis of human normal prostate and prostate cancer cell lines depends on the cell line tested, the time of exposure to LEP and the concentration of this cytokine in the culture medium.

In our study, strong LEP-dependent regulation of apoptotic processes in LNCaP prostate cell line was demonstrated. This pro-apoptotic effect was triggered by LEP at the highest of the tested doses $\left(1 \times 10^{-6} \mathrm{M}\right)$, that affected on expression changes of many apoptotic genes. It is well known that apoptotic process is divided into two stages: induction and execution. Induction of apoptosis is a multifactorial stage of apoptosis, that includes involvement of many different factors, like receptors, ligands, intracellular peptides. Presented here microarray analysis using KEGG "apoptosis" pathway showed that after $48 \mathrm{~h}$ exposure, among 41 DEGs involved in apoptosis most of them-39, was up-regulated in LNCaP cells. For example, the expression of FAS gene, which encodes a cell surface death receptor that play key role in induction of apoptosis by binding FAS ligand (FASLG) in cell membrane, was almost 3 times higher (fold $=2.95, p=0.003$ ), compared to control. This statistically significant increase was also confirmed using qPCR method. Unlike our results, Tanaka and coworkers (2008) demonstrated inhibitory effect of LEP on Fas-dependent apoptosis [55]. This result was obtained using LEP at physiological concentration, indicating the importance of the dose of the peptide administered in the experiments. On the other hand, current studies have shown that another ligand of death receptors involved in induction of apoptosis (mentioned above) - member of TNF superfamily-TNF-alpha, was also found strongly up-regulated after LEP $1 \times 10^{-6} \mathrm{M}$ administration (fold $=4.27, p=0.0001$ ). Moreover, the expression of TRADD gene that encode tumor necrosis factor receptor type 1-associated DEATH domain protein (TRADD) involved in transduction of the TNF-alpha signal downstream, was also found to be increased (fold $=1.47, p=0.01$ ). Similar changes were found in the expression of TP53 gene (p53 protein) (fold $=1.66, p=0.003$ ). As commonly known, p53 protein plays significant role in regulation of progression through apoptosis when DNA damage is irreparable. It activates pro-apoptotic $\mathrm{BH}$ family peptides proteins, like BAX, BID and transcription factors like NOXA, PUMA and direct the cell to death. Here the expression level of those molecules were found to be increased $(\mathrm{BAX}$ fold $=1.31, p=0.048$; $\mathrm{BID}$ fold $=1.43, p=0.021$ ). 
Table 1. Literature data on the effect of leptin (LEP) on proliferation and apoptosis in human normal prostate and prostate cancer cell lines.

\begin{tabular}{|c|c|c|c|c|}
\hline Cell Type & Method of Detection & Dose of LEP and Time & Effect & Reference \\
\hline LNCaP-FGC, DU145, PC-3 & $\begin{array}{l}{[3 \mathrm{H}] \text { thymidine incorporation }} \\
\text { MTT assay }\end{array}$ & $\begin{array}{l}\text { LEP }(0.1-12.5 \mu \mathrm{g} / \mathrm{mL}) \text { for } 20 \mathrm{~h} \\
\operatorname{LEP}(12.5 \mu \mathrm{g} / \mathrm{mL}) \text { for } 5 \text { days }\end{array}$ & $\begin{array}{l}\text { stimulation of proliferation in DU145 and } \\
\text { PC-3 cells but not in LNCaP-FGC cell }\end{array}$ & Onuma et al. (2003) [25] \\
\hline DU145 and PC-3 & MTT assay & $\begin{array}{l}\text { LEP }(0.4 \mathrm{ng} / \mathrm{mL} \text { and } 4.0 \mathrm{ng} / \mathrm{mL}) \text { for } 24 \text { and } \\
48 \mathrm{~h}\end{array}$ & in both cell lines LEP inhibited growth & Somasundar et al. (2003) [52] \\
\hline DU145 and PC-3 & $\begin{array}{l}\text { MTT assay } \\
\text { ELISA }\end{array}$ & $\begin{array}{l}\text { LEP ( } 4 \text { or } 40 \mathrm{ng} / \mathrm{mL} \text { ) for } 24 \text { and } 72 \mathrm{~h} \\
\text { LEP }(4 \text { or } 40 \mathrm{ng} / \mathrm{mL} \text { ) for } 24 \mathrm{~h}\end{array}$ & $\begin{array}{l}\text { stimulation of proliferation in both cell } \\
\text { lines increased apoptosis in both cell lines }\end{array}$ & Somasundar et al. (2004) [53] \\
\hline DU145 & {$[3 \mathrm{H}]$ thymidine incorporation } & $\operatorname{LEP}(12.5 \mu \mathrm{g} / \mathrm{mL})$ for $20 \mathrm{~h}$ & stimulation of proliferation & Miyazaki et al. (2008) [29] \\
\hline LNCaP, DU-145 and PC-3 & {$[3 \mathrm{H}]$ thymidine incorporation } & LEP $(20-200 \mathrm{ng} / \mathrm{mL})$ for $144 \mathrm{~h}$ & $\begin{array}{l}\text { stimulation of proliferation of LNCaP } \\
\text { cells, no effects on PC-3 and Du- } 145 \text { cells }\end{array}$ & Deo et al. (2008) [27] \\
\hline DU145 and PC-3 & $\begin{array}{c}\text { XTT colorimetric assay (tetrazolium based } \\
\text { assay) } \\
\text { Cell death detection ELISA plus }{ }^{\circledR} \text { assay }\end{array}$ & $\begin{array}{l}\text { LEP }(5-100 \mathrm{ng} / \mathrm{mL}) \text { for up to } 48 \mathrm{~h} \\
\quad \operatorname{LEP}(100 \mathrm{ng} / \mathrm{mL}) \text { for } 24 \mathrm{~h}\end{array}$ & $\begin{array}{l}\text { stimulation of proliferation in both cell } \\
\text { lines anti-apoptotic effects }\end{array}$ & Hoda \& Popken (2008) [54] \\
\hline LNCaP and PC3 & $\begin{array}{l}\text { CellTiter } 96^{\circledR} \text { AQueous One Solution Cell } \\
\text { Proliferation Assay (tetrazolium based assay) }\end{array}$ & LEP $(0.01-100 \mathrm{nM})$ for $48 \mathrm{~h}$ & $\begin{array}{l}\text { proliferation in LNCaP cells unaffected, } \\
\text { in PC3 cells significantly increased }\end{array}$ & Mistry et al. (2008) [26] \\
\hline $\begin{array}{l}\text { LNCaP-FGC, DU-145, PC-3, and PC-3 } \\
\text { cells stably expressing AR (androgen } \\
\text { receptor)-PC-3/AR }\end{array}$ & $\begin{array}{l}\text { apoptosis effector protein caspase } 3 \text { levels, } \\
\text { cleavage of the DNA repair enzyme, and the } \\
\text { numbers of apoptotic cells visualized by } \\
\text { Hoechst } 33342\end{array}$ & $\operatorname{LEP}(1 \mathrm{ng} / \mathrm{mL})$ for $24 \mathrm{~h}$ & $\begin{array}{l}\text { In all studied cell lines statistically } \\
\text { significant pro-apoptotic effects of LEP }\end{array}$ & Samuel-Mendelsohn et al. (2011) [35] \\
\hline $\begin{array}{l}\text { samples of human hyperplastic } \\
\text { prostate tissue }\end{array}$ & $\begin{array}{c}\text { cell proliferation evaluated by } \\
\text { immunohistochemistry for PCNA, RT-PCR } \\
\text { (expression of apoptosis related genes) }\end{array}$ & incubation with LEP $(50 \mathrm{ng} / \mathrm{mL}$ ) for $3 \mathrm{~h}$ & $\begin{array}{l}\text { stimulation of cell proliferation (ca } \\
\text { 3-folds) and BAX expression, lowered } \\
\text { expression levels of BCL-2 and BCL-X } \\
\text { in all cell lines no effects on cell }\end{array}$ & Leze et al. (2012) [23] \\
\hline LNCaP, DU145 and PC-3 & WST- 8 assays and a Cell Counting kit-8 & LEP (up to $1000 \mathrm{ng} / \mathrm{mL}$ ) for $48 \mathrm{~h}$ & $\begin{array}{l}\text { proliferation, LEP }(100 \mathrm{ng} / \mathrm{mL}) \text { - cell } \\
\text { number notably increased between days } \\
7-42 \text { of culture }\end{array}$ & Noda et al. (2015) [28] \\
\hline $\begin{array}{c}\text { human normal prostate (PrEC, PrSC, } \\
\text { PrSMC) and prostate cancer (DU145, } \\
\text { LNCaP, PC3) cell lines }\end{array}$ & $\begin{array}{l}\text { proliferative activity was determined by RTCA } \\
\text { (real-time cell analyzer) }\end{array}$ & $\begin{array}{c}\operatorname{LEP}\left(1 \times 10^{-6}, 1 \times 10^{-8} \text { and } 1 \times 10^{-10} \mathrm{M}\right) \\
\text { for at least } 70 \mathrm{~h}\end{array}$ & $\begin{array}{l}\text { lowered proliferation rate of LNCaP cells } \\
\text {-at } 1 \times 10^{-6} \mathrm{M} \text { LEP concentration, } \\
\text { increased proliferation rate of DU145 } \\
\text { cells at the same concentration, increased } \\
\text { proliferation rate of PrSC cells at } 1 \times 10^{-8} \\
\text { and } 1 \times 10^{-10} \mathrm{M} \text { LEP concentrations. In } \\
\text { all remaining tests LEP did not influence } \\
\text { the proliferation rate of the studied cells }\end{array}$ & Szyszka et al. (2018) [24] \\
\hline
\end{tabular}


Activation of death domain receptors leads to activation of initiating caspases 8 and 10, which next, on the one hand, activates pro-apoptotic protein BID and on the other hand, activates procaspases 3 and 7-inactive forms of effector caspases 3 and 7 (CASP3, CASP7). This is followed by avalanche activation of target proteins, leading to cell death. Active protein BID activates other pro-apoptotic $\mathrm{BH}$ family peptides-BAX and BAK, which lead to the release of cytochrome $C$ from the mitochondrial matrix and form apoptosome complex, while active caspase 3 cleavage the DNA repair enzyme (PARP) into active form. In our study, the expression level of several mentioned above genes involved in progression of apoptosis, were clearly elevated (CASP8 fold $=1.81, p=0.002 ;$ CASP10 fold $=1.42$, $p=0.019 ; C A S P 7$ fold $=2.53, p=0.001)$. In the literature there is lot of data regarding involvement of LEP in the regulation of apoptotic processes in prostatic cells. Most of them indicated inhibitory effect of LEP on this process and promotion of cellular proliferation $[20,28,52,54,56,57]$. However, some studies demonstrated LEP-dependent activation of apoptotic processes. Regarding this Samuel-Mendelsohn et al. (2011) reported LEP-induced activation of apoptotic effector molecules (CASP3 and PARP) in LNCaP cells [35]. Using Western-blot analysis followed by densitometry quantification they noted dose-dependent increase in CASP3 and PARP level observed between 6 and 24-h of LEP administration $(1 \mathrm{ng} / \mathrm{mL}$ of LEP). This result is in line with the results presented here. Despite the fact that we didn't notice increase of expression of CASP3 mRNA, we detected increased expression of PARP mRNA in LNCaP cells (described on the signal path as PARP, mapped as PARP4 fold $=1.33, p=0.038$ ). Other studies of Kim and coworkers (2003) demonstrated LEP-dependent activation of caspase 3 and caspase 9 in osteoblast-lineage of primary human bone marrow stromal cells [57]. This caused increase of cytochrome $c$ release from mitochondria and could confirm our finding on LEP-activation of apoptosis, however we didn't note any changes in expression level of both caspases mRNA [57]. Although most genes belonging to the ontological group "apoptotic process" were up-regulated, as well as enrichment analysis of ontological groups indicated a significant stimulation of this process, several genes involved in the regulation of apoptosis are lowered under the influence of LEP, e.g., PEG3, DAPK1, ZBTB16, STK3 and AR. It is well described that proliferation and growth of LNCaP cells is androgen dependent, where AR plays proliferative or/and apoptotic role by interaction with MAPK, EGFR, IGF, TGF beta, FGF or VEGF [58-61]. For this reason, we cannot exclude an indirect involvement of the androgen receptor in the observed LEP effect. However, this aspect requires further research.

We are aware that the research was carried out with the use of high LEP concentrations in the culture medium. However, similar LEP concentrations are also used in other in vitro experiments [62-66]. For example, such high LEP concentrations are used in studies related to the involvement of LEP in the regulation of pituitary gland hormone secretion or cell proliferation. In concentrations comparable to our own LEP inhibits pituitary cell proliferation in human and rat pituitary cell lines in vitro [61], stimulates FSH and LH release from pituitary cells of male and female rainbow trout [64] and TSH secretion from ovine pituitary cells [63]. As mentioned above, LEP concentration used is far from the physiological. Therefore, the use of high LEP doses in systemic administration seems to be a limiting factor, due to possible side effects. However, the potential use of high doses of LEP administered directly to the prostate should be taken into consideration. It should also be noted that LEP and its receptor are expressed within the prostate, therefore its local para and autocrine activity are not excluded, where in the intercellular areas the leptin level may be higher than in the serum. Additionally, there are numerous depots of adipose cells within the prostate that may constitute a source of locally acting leptin. This suggestion is reinforced by the fact that the expression of LEP, leptin receptor (LEPR) and its main downstream signaling genes (JAK2, STAT3) is reduced in prostate adenocarcinoma (Figure 11), suggesting that this system is involved in the mechanism of apoptosis defense in proliferating tumor cells. However, this suggestion requires further studies. 


\section{Materials and Methods}

\subsection{Prostate Cancer Cell Line}

LNCaP — the human prostate carcinoma cell line (LNCaP clone FGC (ATCC ${ }^{\circledR}$ CRL-1740DTM)) was purchased from ATCC (American Type Culture Collection, Manassas, Rockville, MD, USA). LNCaP cells were cultivated in the RPMI Medium $1640(1 \times)$, supplemented with GlutaMAX, HEPES (all from Gibco, Life technologies, Carlsbad, CA, USA) and antibiotics (Antibiotic/antimycotic Sigma Aldrich, Saint Louis, MO, USA). Cells were grown in the $75 \mathrm{~cm}^{2}$ flask (NUNC EasyFlask with Nunclon surface, Thermo Fisher Scientific) at $37{ }^{\circ} \mathrm{C}$ in a humidified atmosphere of $5 \% \mathrm{CO}_{2}$. The culture medium was changed every 2 days [67]. When cells reached approximately 80\% confluence (about 7-8 days of cultivation), they were subcultured into 6-well plates (Nunc, Thermo Fisher Scientific, approximately 343,000 cells per one well $-9.6 \mathrm{~cm}^{2}$ ), to determine the effect of LEP on LNCaP cells proliferation at mRNA/protein level. Simultaneously, cells were seeded on E-Plate 48 (Roche Applied Science, GmbH, Penzberg, Germany or ACEA Biosciences Inc., San Diego, CA, USA, approximately 12,500 cells per one well $-0.3 \mathrm{~cm}^{2}$ ) to perform real time proliferation assay [24]. The applied experimental protocol was as follows: during the first $48 \mathrm{~h}$ of cultivation, the cells grew in a standard medium mentioned above. For the next $24 \mathrm{~h}$, the cells were grown in starvation medium (FBS free). Afterwards, the cells were cultivated for $48 \mathrm{~h}$, in a starvation medium supplemented with LEP (Recombinant Human Leptin, PeproTech, Germany) at the following concentrations: 0 (control), $1 \times 10^{-6} ; 1 \times 10^{-8}$ and $1 \times 10^{-10} \mathrm{M}$. After the mentioned period, the medium and cell supernatants were collected and stored at $-80{ }^{\circ} \mathrm{C}$ for further analyses.

\subsection{Real-Time Proliferation Assay}

To verify proliferation rate of LNCaP cells we used an electrical impedance based approach-the Real-Time Cell Analyser (RTCA, Roche Applied Science, GmbH, Penzberg, Germany). The system detects variations in electrical impedance across incorporated sensor electrode arrays placed on the bottom of 16-well chamber slide plates (E-plate 16) on which the cells are seeded. Electrical impedance is measured throughout the cultivation period at a 15-minutes frequency. The main read-out of the RTCA is a dimensionless parameter named "Cell Index" which represents a relative change in electrical impedance, depending on the proliferation or apoptosis rate of the cultured cells. LNCaP cells were cultivated in the same groups and experimental layout as described above. Each group was seeded in the eight wells of E-plates in a final volume of $200 \mu \mathrm{L}$ per well. Cell index was normalised (normalised cell index) at the time point of LEP administration, using software provided by the manufacturer (RTCA Software, Version 1.2, November 2009). LNCaP cells were cultivated with LEP till reaching the plateau phase in the control group (total time: $196 \mathrm{~h}$ ). Each experiment was repeated at least three times.

\subsection{Flow Cytometry Analysis of Cleaved PARP-1}

LNCaP cells (un- and treated with different concentrations of leptins) were stained for cPARP with the PE Mouse Anti-Cleaved PARP (Asp214) antibody (562253, BD Biosciences, NJ, USA) according to manufacturer's instructions. Briefly, $1 \times 10^{6}$ un- and treated cells were fixed and permeabilized with BD Cytofix/Cytoperm Fixation/Permeabilization Solution for $30 \mathrm{~min}$ at room temperature. Then, the additional permeabilization and fixation was performed. The fixed cells were washed with BD Perm/Wash Buffer and stained with appropriate antibody ( $5 \mu \mathrm{L} /$ test $)$ for $20 \mathrm{~min}$ at room temperature. The stained and washed cells were resuspended in $500 \mu \mathrm{L}$ PBS and analyzed with a flow cytometer (CytoFLEX, Beckman Coulter, CA, USA). Fluorescence intensity in arbitrary units was plotted in histograms and the mean fluorescence intensity was calculated. Data were analyzed using FlowJo software (FlowJo v10; LLC, Ashland, OR, USA). 


\subsection{RNA Isolation}

The applied methods were described earlier [68]. The total RNA was extracted using TRI Reagent (Sigma-Aldrich, St. Louis, MO, USA) then purified on columns (NucleoSpin Total RNA Isolation, Qiagen $\mathrm{GmbH}$, Hilden, Germany). The amount of total RNA was determined by optical density at $260 \mathrm{~nm}$ and its purity was estimated by $260 / 280 \mathrm{~nm}$ absorption ratio (higher than 1.8) (NanoDrop spectrophotometer, Thermo Scientific, Waltham, MA, USA). The RNA integrity and quality were checked in a Bioanalyser 2100 (Agilent Technologies, Inc., Santa Clara, CA, USA). The resulting RNA integrity numbers (RINs) were between 8.5 and 10 with an average of 9.2. Each sample was diluted to the RNA concentration of $100 \mathrm{ng} / \mu \mathrm{L}$, at the OD260/OD280 ratio of 1.8/2.0. From each RNA sample, $100 \mathrm{ng}$ of RNA was taken for microarray experiments. The remaining amount of isolated RNA was used for RT-qPCR study.

\subsection{Reverse Transcription}

Reverse transcription was performed using Transcriptor High Fidelity Reverse Transcriptase enzyme blend for high fidelity two-step RT-PCR of RNA (Roche, Basel, Switzerland) with Oligo(dT) as primers at a temperature of $45^{\circ} \mathrm{C}$ for $40 \mathrm{~min}$ (Thermocycler UNO II, Biometra, Göttingen, Germany). For a single reaction, $1 \mu \mathrm{g}$ of total RNA was used. The RT was carried out in standard final volumes $(20 \mu \mathrm{L})$. After RT each cDNA containing sample was diluted with $100 \mu \mathrm{L}$ of RNase-free water.

\section{6. $Q-P C R$}

Q-PCR was performed using the Lightcycler 2.0 instrument (Roche, Basel, Switzerland) with the 4.05 software version. SYBR green detection system was applied as described earlier [67]. Every of $20 \mu \mathrm{L}$ reaction mixtures contained $2 \mu \mathrm{L}$ template cDNA (standard or control), $0.5 \mu \mathrm{M}$ of specific primer and a previously determined optimum $\mathrm{MgCl}_{2}$ concentration ( $3.5 \mu \mathrm{M}$ for one reaction). Light Cycler Fast Start DNA Master SYBR Green I mix (Roche) was used. The real-time PCR program included 10 min denaturation step to activate the Taq DNA Polymerase, followed by a three-step amplification program: denaturation at $95{ }^{\circ} \mathrm{C}$ for $10 \mathrm{~s}$, annealing at $56^{\circ} \mathrm{C}$ for $5 \mathrm{~s}$, and extension at $72{ }^{\circ} \mathrm{C}$ for $10 \mathrm{~s}$. Specificity of reaction products was checked by determination of melting points $\left(0.1^{\circ} \mathrm{C} / \mathrm{s}\right.$ transition rate). All samples were amplified in triplicate, and hypoxanthine phosphoribosyltransferase (HPRT) gene was used as a reference to normalize obtained results.

The primers were designed using Primer 3 software (Whitehead Institute for Biomedical Research, Cambridge, MA, USA) (Table 2). They were purchased from the Laboratory of DNA Sequencing and Oligonucleotide Synthesis, Institute of Biochemistry and Biophysics, Polish Academy of Sciences, Warsaw.

Table 2. Oligonucleotide sequences of sense (S) and antisense (A) primers.

\begin{tabular}{|c|c|c|c|c|c|}
\hline Gene Symbol & Genbank Accession Number & Primer & Primer Sequence $\left(5^{\prime}-3^{\prime}\right)$ & Position & $\begin{array}{l}\text { PCR Product } \\
\text { Size (bp) }\end{array}$ \\
\hline \multirow{2}{*}{$B M X$} & NM_203281.3 & S & CATCGGACACCATCTACCAG & $2053-2072$ & \multirow{2}{*}{278} \\
\hline & BMX non-receptor tyrosine kinase & A & CTTTTGTTTCCTGCCTTGTTC & $2310-2330$ & \\
\hline \multirow{2}{*}{ C11orf92 } & NM_001302644.1 & S & AGCAAGAATATCACCGTGAAGCA & $129-151$ & \multirow[b]{2}{*}{184} \\
\hline & chromosome 11 open reading frame 92 & $\mathrm{~A}$ & ACCACGATGTCGGGTAACTC & $293-312$ & \\
\hline \multirow[b]{2}{*}{ KLK4 } & NM_004917.4 & $\mathrm{S}$ & CTCTATGACCCGCTGTACCAC & $541-561$ & \multirow[b]{2}{*}{123} \\
\hline & kallikrein-related peptidase 4 & A & CACAAGGCCCTGCAAGTACC & $644-663$ & \\
\hline \multirow{2}{*}{$M Y L K$} & NM_053025.4 & $S$ & AAGTGCTGCTAGATTTGACT & $5781-5800$ & \multirow{2}{*}{136} \\
\hline & myosin light chain kinase & A & AATTAAAGAGCAGTTCCCGTC & $5896-5916$ & \\
\hline \multirow{2}{*}{ RIMS1 } & \multirow{2}{*}{$\begin{array}{l}\text { NM_014989.5 } \\
\text { regulating synaptic membrane } \\
\text { exocytosis } 1\end{array}$} & $\mathrm{~S}$ & AATATTTCCTGGAGTGCGACTGG & $4830-4852$ & \multirow{2}{*}{179} \\
\hline & & A & GGCTTCGTGCTCTAATGACTT & $4988-5008$ & \\
\hline \multirow{2}{*}{$M M P 7$} & NM_002423.4 & S & ATGATATTAAAGGCATTCAGA & $799-819$ & \multirow{2}{*}{281} \\
\hline & matrix metallopeptidase 7 & A & TTTATTGACATCTACCCACT & $1060-1079$ & \\
\hline \multirow{2}{*}{ TNF IP3 } & NM_001270508.1 & S & CCATCATTTTGTACCCTTG & $1132-1150$ & \multirow{2}{*}{280} \\
\hline & $\begin{array}{c}\text { TNF alpha induced protein } 3 \text { transcript } \\
\text { variant } 1\end{array}$ & A & TTCAAGTAATCATCTACCAG & $1391-1411$ & \\
\hline
\end{tabular}


Table 2. Cont.

\begin{tabular}{|c|c|c|c|c|c|}
\hline Gene Symbol & Genbank Accession Number & Primer & Primer Sequence $\left(5^{\prime}-3^{\prime}\right)$ & Position & $\begin{array}{l}\text { PCR Product } \\
\text { Size (bp) }\end{array}$ \\
\hline \multirow{2}{*}{ FAS } & \multirow{2}{*}{$\begin{array}{c}\text { NM_000043.5 } \\
\text { Fas cell surface death receptor } \\
\text { transcript variant } 1\end{array}$} & S & CAAAAGTGTTAATGCCCAA & $378-396$ & \multirow{2}{*}{299} \\
\hline & & A & TGCAGTTTATTTCCACTTC & $658-676$ & \\
\hline \multirow{2}{*}{ BIRC3 } & \multirow{2}{*}{$\begin{array}{l}\text { NM_001165.4 } \\
\text { baculoviral IAP repeat containing } 3 \\
\text { transcript variant } 1\end{array}$} & S & TAGTAAAAGGAAATATTGCAG & $4294-4314$ & \multirow{2}{*}{100} \\
\hline & & A & TATTTTATGTCCTGTTGCAC & $4374-4393$ & \\
\hline \multirow{2}{*}{ HPRT } & NM_000194.2 & S & GCCATCACATTGTAGCССТC & $343-362$ & \multirow{2}{*}{172} \\
\hline & $\begin{array}{l}\text { hypoxanthine } \\
\text { phosphoribosyltransferase } 1\end{array}$ & A & ACTTTTATGTCCCCTGTTGACT & $493-514$ & \\
\hline
\end{tabular}

\subsection{Microarray Expression Study}

The microarray study was carried out according to the previously described procedure [69-72]. The previously isolated RNA was pooled into four samples, representing control group $(n=2)$ and experimental group $(n=2)$ where the RNA was isolated after 24 hours from LEP administration (concentration $1 \times 10^{-6} \mathrm{M}$ ). The protocol involving transcription in vitro, biotin labelling and cDNA fragmentation for further hybridization was carried out using the Affymetrix GeneChip IVT Express Kit (Affymetrix, Santa Clara, CA, USA). Obtained biotin-labelled fragments were hybridized with Affymterix GeneChip Human Genome U219 microarrays together with control cDNA and oligo B2. The hybridization process was conducted with the use of the AccuBlockTM Digital Dry Bath (Labnet International, Inc., Edison, NJ, USA) hybridization oven at $45^{\circ} \mathrm{C}$ for $16 \mathrm{~h}$. Then the microarrays were washed and stained according to the technical protocol using the Affymetrix GeneAtlas Fluidics Station (Affymetrix, Santa Clara, CA, USA). The array strips were scanned by the Imaging Station of GeneAtlas System. Preliminary analysis of the scanned chips was performed using Affymetrix GeneAtlasTM Operating Software. The quality of gene expression data was verified using the quality control criteria established by the software. Obtained CEL files were imported into downstream data analysis.

\subsection{Microarray Data Analysis}

All analyses were performed using BioConductor software with the relevant Bioconductor libraries, based on the statistical R programming language. The Robust Multiarray Average (RMA) normalization algorithm implemented in the "Affy" library was used for normalization, background correction, and calculation of the expression values of all of the examined genes [73]. Biological annotation was taken from BioConductor "oligo" package where annotated data frame object was merged with normalized data set, leading to a complete gene data table [74]. Differential expression and statistical assessment were determined by applying the linear models for microarray data implemented in the "limma" library [75]. The selection criteria of a significantly changed gene expression were based on fold difference higher than absolute 2 and $p$-value after false discovery rate (FDR) correction $<0.05$. The result of such a selection was presented as volcano plot, showing the total number of up- and down-regulated genes. Raw Data files were also deposited in the Gene Expression Omnibus (GEO) repository at the National Center for Biotechnology Information (http://www.ncbi.nlm.nih.gov/geo/) under the GEO accession number GEO: GSE133616.

\subsection{Assignment of Differentially Expressed Genes to Relevant Gene Ontology (GO) Terms}

The whole set of differentially expressed genes (DEGs) were subjected to functional annotation and clusterization using the DAVID (Database for Annotation, Visualization, and Integrated Discovery) bioinformatics tool [76]. Gene symbols of differentially expressed genes were uploaded to DAVID by the "RDAVIDWebService" BioConductor library [77], where DEGs were assigned to relevant GO terms, with subsequent selection of significantly enriched GO terms from GO BP Direct database. The p-values of selected GO terms were corrected using Benjamini-Hochberg correction described as adjusted p-values [78]. Relevant GO ontological groups with adjusted $p$-values below 0.05 and $\mathrm{N}$ per group $>5$ were visualized using bubble plot. Detailed analysis of genes belonging to selected 
ontological groups, with their expression fold changes, are presented as circos plots using "GOplot" library [79].

\subsection{Gene Set Enrichment Analysis (GSEA)}

Gene Set Enrichment Analysis was used to determine enrichment or depletion in genes expression between two compared biological groups within a priori defined gene sets (GO terms, pathways). The method uses Kolmogorov-Smirnov (K-S) statistical test for identification of significantly enriched or depleted groups of genes [80]. GSEA analysis has been conducted using FGSEA library [81]. Normalised fold change values from all of the genes presented on the microarray were $\log 2$ transformed and ordered. Then, a predefined gene sets from Hallmark database (from the Molecular Signatures Database) was selected [82]. Genes belonging to the selected set were ranked according to the difference in their expression level using signal-to-noise ratio with 1000 times permutation. By walking down the ranked list of genes, the enrichment score (ES) was calculated for each selected gene set [83]. ESs were normalized by their gene set size, and false positives were corrected by FDR.

\subsection{KEGG Signaling Pathways}

The Pathview library of the bioconductor was used to generate the p53 and apoptosis signaling pathway [84]. The fold values of significantly changed genes were mapped by colours on native KEGG, p53 (KEGG ID = hsa04115) and apoptosis signaling pathway (KEGG ID = hsa04210), where green represents up-regulated expression and red represents down-regulated expression levels in relation to the control group. In order to show a comprehensive image concerning the regulation of the analysed signaling pathways, all genes whose expression was significantly different without a cut-off at fold values were visualized.

\subsection{Western Blot Analysis}

Cell supernatant was homogenized in RIPA buffer (Sigma Aldrich, St. Louis, MO, USA) with addition of EDTA-free Protease Inhibitor Coctail (Roche, Basel, Switzerland). The concentration of isolated proteins was determined by Bradford Protein Assay (Bio-Rad, CA, USA) [85]. The electrophoresis was conducted on $4-20 \%$ Mini Protean TGX Preacast electrophoretic gel (Mini-Protein TGX Bio-Rad) with Tris/Glycine/SDS Buffer (Bio-Rad, CA, USA, no: 1610732). The first gel pocket was filled with markers PageRuler Plus Prestained Protein Ladder (Thermofisher Scientific, Waltham, MA, USA, no 26619). For each sample, $20 \mu \mathrm{g}$ of protein was separated and transferred onto a PVDF membrane using Trans-Blot Turbo RTA Mini Nitrocellulose Transfer System (Bio-Rad, CA, USA, no: 1704270). Transferred proteins were stained with Ponceau S. Membranes were incubated in a blocking buffer consisting of 5\% non-fat dry milk in TBST for $1 \mathrm{~h}$, followed by primary antibody incubation overnight at $4{ }^{\circ} \mathrm{C}$ with primary antibody (Cell Signaling Technology, Danvers, Massachusetts, USA): p38 MAPK (cat. no: \#8690), p44-42 MAPK (cat. no: \#4695), Phospho Bcl-2 (Thr56) (cat. no: \#2875), Stat1 (cat. no: \#9172), GAPDH (cat. no: sc-47724, Santa Cruz, CA, USA) at dilution 1:1000. Subsequently, membranes were thoroughly washed and incubated with an anti-rabbit IgG HRP-linked antibody in 1:10,000 dilution (\#7074; Cell Signaling Technology) for $1 \mathrm{~h}$ at room temperature. After washing, membranes were incubated with enhanced chemiluminescence (SuperSignal West Femto Maximum Sensitivity Substrate (\#34096 Thermofisher Scientific, Waltham, MA, USA) detection reagents (1 $\mathrm{min}$, room temperature) and visualized on ProteinSimple-Western Blot FluorChem Systems with AlphaView software (ProteinSimple, San Jose, CA, USA). Densitometric analysis was performed in relation to GAPDH.

\subsection{ELISA Test-MMP7 Level Detection}

The culture medium from control and LEP $1 \times 10^{-6} \mathrm{M}$ groups was subjected to an analysis of the metalloproteinase 7 (MMP7) secretion level using solid phase enzyme-linked immunosorbent assay (ELISA) test (Abcam, Cambridge, UK, ab100608, MMP7 Human ELISA Kit). All assays were performed 
according to the manufacturers' protocols. Absorbance (OD) of each plate wells were measured at $450 \mathrm{~nm}$ with Biotek - synergy 2, microtiter plate reader. Quantitative analysis was performed using a Four-Parameter Logistic (4PL) curve, implemented in "drc" package of Bioconductor [86].

\subsection{Expression of Leptin System in Normal Prostate and Tumor Tissues-Analysis of The Cancer Genome} Atlas (TCGA) Dataset

Clinical description with RNAseq data for 52 normal prostate (control) and 498 prostate adenocarcinoma were downloaded from public TCGA database [87] using FireBrowse server (http://gdac.broadinstitute.org/) [88]. Then voom algorithm from "Limma" package was used for data normalization [75]. Normalized data for leptin (LEP), leptin receptor (LEPR) and its main downstream signaling genes (JAK2, STAT3), were extracted from the whole dataset. The obtained expression values were subjected to statistical analysis using Mann-Whitney test and visualised as boxplots with medians and interquartile ranges (IQR).

\subsection{Statistics}

Statistical evaluation of the differences between groups was carried out using the Student's $t$-test or Mann-Whitney test with asterisk annotation $\left({ }^{*} p<0.05 ;{ }^{* *} p<0.02 ;{ }^{* * *} p<0.01\right)$. Each of the described experiments was repeated at least three times. In the case of data obtained from microarray, differences were evaluated by statistical programs included in particular bioinformatic analyses.

\section{Conclusions}

Obtained results suggest activation of apoptotic processes in LNCaP cells cultured at high LEP concentration. At the same time, this activation is accompanied by inhibition of proliferation of the tested cells.

Author Contributions: M.S.: invented and designed the experiments, performed the microarray experiments, analyzed microarray data; M.T.: performed the experiments, verified all obtained results; L.P.: verified all obtained results, analyzed the data and prepared the manuscript; K.J.: performed real-time PCR studies with subsequent analysis; P.C.: performed the experiments, took part in graphical presentation; G.S.: performed the experiments, took part in graphical presentation; P.M.: performed ELISA studies with subsequent analysis; E.S.: performed the experiments, took part in graphical presentation; A.M.: performed the experiments, took part in graphical presentation; L.K.M.: invented and designed the experiments, analyzed the data and prepared the manuscript; M.R.: invented and designed the experiments, analyzed the data, prepared graphical presentation and prepared the manuscript. All authors took part in preparation and modification of figures and manuscript.

Funding: This research was supported by: "Preludium Grant" program of the National Science Center No. 2011/03/N/NZ3/06095. Gulnara Sultanova (WKMOMU) \& Agnieszka Malinska (PUMS) were supported by the Social Health Insurance Project, Republic of Kazakhstan (Contract No. SHIP-2.3/CS-02).

Conflicts of Interest: The authors declare no conflict of interest.

\section{Abbreviations}

$\begin{array}{ll}\text { AR } & \text { Androgen receptor } \\ \text { BAX } & \text { Bcl-2-like protein } 4 \\ \text { Bcl-2 } & \text { B-cell lymphoma 2 } \\ \text { BID } & \text { BH3 interacting domain death agonist } \\ \text { BIRC3 } & \text { Baculoviral IAP repeat containing 3 } \\ \text { BMX } & \text { BMX non-receptor tyrosine kinase } \\ \text { C11orf92 } & \text { Chromosome 11 open reading frame 92 } \\ \text { CASP3 } & \text { Procaspases 3 } \\ \text { CASP7 } & \text { Procaspases 7 } \\ \text { CCL-20 } & \text { Chemokine C-Cmotif ligand 20 } \\ \text { CNTF } & \text { Ciliary neurotrophic factor }\end{array}$


DAPK1 Death-associated protein kinase 1

DAVID Database for annotation, visualization, and integreted discovery

DEG Differentially expressed genes

EGFR Epidermal growth factor receptor

EMT Epithelial-mesenchymal transition

FAS Fas cell surface death receptor

FASL Fas ligand

FBS Fetal bovine serum

FGF Fibroblast growth factors

FSH Follicle-stimulating hormone

GADD45G Growth arrest and DNA-damage-inducible, gamma

GAPDH Glyceraldehyde 3-phosphate dehydrogenase

GO BP Gene onthlogy biological process

GSEA Gene Set Enrichment Analysis

HPRT Hypoxanthine phosphoribosyltransferase

IGF Insulin-like growth factors

IL-11 Interleukin 11

IL-6 Interleukin 6

IRS Insulin receptor substrates

JAK 2 Janus-activated kinase

KEGG Kyoto Encyclopedia of Genes and Genomes

KLK4 kallikrein-related peptidase 4

LCN2 Lipocalin 2

LEP Leptin

LEPR Leptin receptor

LH Luteinizing hormone

LIF Leukemia inhibitory factor

MAPK Mitogen activated protein kinase

MMP7 Matrix metallopeptidase 7

MYLK Myosin light chain kinase

NES Normalized enrichment score

NF- $\mathrm{B} \quad$ Nuclear factor of kappa

NOXA Phorbol-12-myristate-13-acetate-induced protein 1

PARP Procyclic acidic repetitive proteins

PEG3 Paternally-expressed gene 3 protein

PI3K/Akt Initiating activation of the phosphoinositide 3 kinase

PUMA p53 upregulated modulator of apoptosis

RIMS1 regulating synaptic membrane exocytosis 1

RTCA Real Time Cell Analyzer

Stat Signal transducer and activator of transcription

STK3 Serine/threonine-protein kinase 3

TCGA The Cancer Genome Atlas

TGF Transforming growth factor

TNF Tumor necrosis factor

TNFAIP3 Tumor necrosis factor, alpha-induced protein

TRADD Tumor necrosis factor receptor type 1-associated DEATH domain protein

TSH Thyroid-stimulating hormone

VEGF Vascular endothelial growth factor

ZBTB16 Zinc finger and BTB domain-containing protein 16

\section{References}

1. Lee, D.W.; Leinung, M.C.; Rozhavskaya-Arena, M.; Grasso, P. Leptin and the treatment of obesity: Its current status. Eur. J. Pharmacol. 2002, 440, 129-139. [CrossRef]

2. Bray, G.A. The underlying basis for obesity: Relationship to cancer. J. Nutr. 2002, 132, 3451S-3455S. [CrossRef] 
3. Calle, E.E.; Rodriguez, C.; Walker-Thurmond, K.; Thun, M.J. Overweight, obesity, and mortality from cancer in a prospectively studied cohort of U.S. adults. N. Engl. J. Med. 2003, 348, 1625-1638. [CrossRef]

4. Calle, E.E.; Thun, M.J. Obesity and cancer. Oncogene 2004, 23, 6365-6378. [CrossRef] [PubMed]

5. Renehan, A.G.; Zwahlen, M.; Egger, M. Adiposity and cancer risk: New mechanistic insights from epidemiology. Nat. Rev. Cancer 2015, 15, 484-498. [CrossRef] [PubMed]

6. Goodwin, P.J.; Stambolic, V. Impact of the obesity epidemic on cancer. Annu. Rev. Med. 2015, 66, $281-296$. [CrossRef] [PubMed]

7. Bergstrom, A.; Pisani, P.; Tenet, V.; Wolk, A.; Adami, H.O. Overweight as an avoidable cause of cancer in Europe. Int. J. Cancer 2001, 91, 421-430. [CrossRef]

8. Tong, X.; Ma, Y.; Zhou, Q.; He, J.; Peng, B.; Liu, S.; Yan, Z.; Yang, X.; Fan, H. Serum and tissue leptin in lung cancer: A meta-analysis. Oncotarget 2017, 8, 19699-19711. [CrossRef] [PubMed]

9. Oba, J.; Wei, W.; Gershenwald, J.E.; Johnson, M.M.; Wyatt, C.M.; Ellerhorst, J.A.; Grimm, E.A. Elevated Serum Leptin Levels are Associated With an Increased Risk of Sentinel Lymph Node Metastasis in Cutaneous Melanoma. Medicine (Baltimore) 2016, 95, e3073. [CrossRef] [PubMed]

10. Sanchez-Jimenez, F.; Perez-Perez, A.; de la Cruz-Merino, L.; Sanchez-Margalet, V. Obesity and Breast Cancer: Role of Leptin. Front. Oncol. 2019, 9, 596. [CrossRef]

11. Ribeiro, R.; Monteiro, C.; Catalan, V.; Hu, P.; Cunha, V.; Rodriguez, A.; Gomez-Ambrosi, J.; Fraga, A.; Principe, P.; Lobato, C.; et al. Obesity and prostate cancer: Gene expression signature of human periprostatic adipose tissue. BMC Med. 2012, 10, 108. [CrossRef] [PubMed]

12. Hoda, M.R.; Theil, G.; Mohammed, N.; Fischer, K.; Fornara, P. The adipocyte-derived hormone leptin has proliferative actions on androgen-resistant prostate cancer cells linking obesity to advanced stages of prostate cancer. J. Oncol. 2012, 2012, 280386. [CrossRef] [PubMed]

13. Hoda, M.R.; Mohammed, N.; Theil, G.; Fischer, K.; Fornara, P. Obesity and prostate cancer. Role of adipocytokines and clinical implications. Urologe A 2012, 51, 1253-1260. [CrossRef] [PubMed]

14. Cao, Y.; Giovannucci, E. Obesity and Prostate Cancer. Recent Results Cancer Res. 2016, 208, 137-153. [PubMed]

15. Allott, E.H.; Masko, E.M.; Freedland, S.J. Obesity and prostate cancer: Weighing the evidence. Eur. Urol. 2013, 63, 800-809. [CrossRef] [PubMed]

16. Ribeiro, R.; Lopes, C.; Medeiros, R. The link between obesity and prostate cancer: The leptin pathway and therapeutic perspectives. Prostate Cancer Prostatic Dis. 2006, 9, 19-24. [CrossRef] [PubMed]

17. Malendowicz, W.; Rucinski, M.; Macchi, C.; Spinazzi, R.; Ziolkowska, A.; Nussdorfer, G.G.; Kwias, Z. Leptin and leptin receptors in the prostate and seminal vesicles of the adult rat. Int. J. Mol. Med. 2006, 18, 615-618. [CrossRef]

18. Malendowicz, W.; Rucinski, M.; Belloni, A.S.; Ziolkowska, A.; Nussdorfer, G.G.; Kwias, Z. Real-time PCR analysis of leptin and leptin receptor expression in the rat prostate, and effects of leptin on prostatic acid phosphatase release. Int. J. Mol. Med. 2006, 18, 1097-1100. [CrossRef]

19. Colli, S.; Silveira Cavalcante, F.; Peixoto Martins, M.; Sampaio, F.J.; da Fonte Ramos, C. Leptin role in the rat prostate ventral lobe. Fertil. Steril. 2011, 95, 1490-1493. [CrossRef]

20. Habib, C.N.; Al-Abd, A.M.; Tolba, M.F.; Khalifa, A.E.; Khedr, A.; Mosli, H.A.; Abdel-Naim, A.B. Leptin influences estrogen metabolism and accelerates prostate cell proliferation. Life Sci. 2015, 121, 10-15. [CrossRef]

21. Cioffi, J.A.; Shafer, A.W.; Zupancic, T.J.; Smith-Gbur, J.; Mikhail, A.; Platika, D.; Snodgrass, H.R. Novel B219/OB receptor isoforms: Possible role of leptin in hematopoiesis and reproduction. Nat. Med. 1996, 2, 585-589. [CrossRef] [PubMed]

22. Malendowicz, W.; Kwias, Z. Leptin receptor isoforms in benign prostatic hyperplasia (Bph). Bph and prostate cancer-No association between plasma concentrations of leptin and prostate specific antigen (pSa). Cent. Eur. J. Urol. 2009, 62, 96-100. [CrossRef]

23. Leze, E.; Alves-Pereira, J.L.; Colli, S.; Cavalcante, F.S.; Jose Sampaio, F.; da Fonte Ramos, C. Leptin regulates proliferation and apoptosis in human prostate. Sci. World J. 2012, 2012, 842301. [CrossRef] [PubMed]

24. Szyszka, M.; Tyczewska, M.; Milecka, P.; Jopek, K.; Celichowski, P.; Malendowicz, L.K.; Rucinski, M. Effects of leptin on leptin receptor isoform expression and proliferative activity in human normal prostate and prostate cancer cell lines. Oncol. Rep. 2018, 39, 182-192. [CrossRef] [PubMed] 
25. Onuma, M.; Bub, J.D.; Rummel, T.L.; Iwamoto, Y. Prostate cancer cell-adipocyte interaction: Leptin mediates androgen-independent prostate cancer cell proliferation through c-Jun NH2-terminal kinase. J. Biol. Chem. 2003, 278, 42660-42667. [CrossRef] [PubMed]

26. Mistry, T.; Digby, J.E.; Desai, K.M.; Randeva, H.S. Leptin and adiponectin interact in the regulation of prostate cancer cell growth via modulation of p53 and bcl-2 expression. BJU Int. 2008, 101, 1317-1322. [CrossRef] [PubMed]

27. Deo, D.D.; Rao, A.P.; Bose, S.S.; Ouhtit, A.; Baliga, S.B.; Rao, S.A.; Trock, B.J.; Thouta, R.; Raj, M.H.; Rao, P.N. Differential effects of leptin on the invasive potential of androgen-dependent and -independent prostate carcinoma cells. J. BioMed Biotechnol. 2008, 2008, 163902. [CrossRef]

28. Noda, T.; Kikugawa, T.; Tanji, N.; Miura, N.; Asai, S.; Higashiyama, S.; Yokoyama, M. Longterm exposure to leptin enhances the growth of prostate cancer cells. Int. J. Oncol. 2015, 46, 1535-1542. [CrossRef]

29. Miyazaki, T.; Bub, J.D.; Iwamoto, Y. C-Jun NH(2)-terminal kinase mediates leptin-stimulated androgen-independent prostate cancer cell proliferation via signal transducer and activator of transcription 3 and Akt. Biochim. Biophys. Acta 2008, 1782, 593-604. [CrossRef]

30. Ghasemi, A.; Saeidi, J.; Azimi-Nejad, M.; Hashemy, S.I. Leptin-induced signaling pathways in cancer cell migration and invasion. Cell. Oncol. 2019, 42, 243-260. [CrossRef]

31. Dutta, D.; Ghosh, S.; Pandit, K.; Mukhopadhyay, P.; Chowdhury, S. Leptin and cancer: Pathogenesis and modulation. Indian J. Endocrinol. Metab. 2012, 16 (Suppl. 3), S596-S600. [PubMed]

32. Gorska, E.; Popko, K.; Stelmaszczyk-Emmel, A.; Ciepiela, O.; Kucharska, A.; Wasik, M. Leptin receptors. Eur. J. Med. Res. 2010, 15 (Suppl. 2), 50-54.

33. Huang, C.Y.; Yu, H.S.; Lai, T.Y.; Yeh, Y.L.; Su, C.C.; Hsu, H.H.; Tsai, F.J.; Tsai, C.H.; Wu, H.C.; Tang, C.H. Leptin increases motility and integrin up-regulation in human prostate cancer cells. J. Cell. Physiol. 2011, 226, 1274-1282. [CrossRef] [PubMed]

34. Fruhbeck, G. Intracellular signalling pathways activated by leptin. Biochem. J. 2006, 393 Pt 1, 7-20. [CrossRef] [PubMed]

35. Samuel-Mendelsohn, S.; Inbar, M.; Weiss-Messer, E.; Niv-Spector, L.; Gertler, A.; Barkey, R.J. Leptin signaling and apoptotic effects in human prostate cancer cell lines. Prostate 2011, 71, 929-945. [CrossRef] [PubMed]

36. Faggioni, R.; Feingold, K.R.; Grunfeld, C. Leptin regulation of the immune response and the immunodeficiency of malnutrition. FASEB J. 2001, 15, 2565-2571. [CrossRef]

37. Loffreda, S.; Yang, S.Q.; Lin, H.Z.; Karp, C.L.; Brengman, M.L.; Wang, D.J.; Klein, A.S.; Bulkley, G.B.; Bao, C.; Noble, P.W.; et al. Leptin regulates proinflammatory immune responses. FASEB J. 1998, 12, 57-65. [CrossRef]

38. Santos-Alvarez, J.; Goberna, R.; Sanchez-Margalet, V. Human leptin stimulates proliferation and activation of human circulating monocytes. Cell. Immunol. 1999, 194, 6-11. [CrossRef]

39. Malinen, M.; Niskanen, E.A.; Kaikkonen, M.U.; Palvimo, J.J. Crosstalk between androgen and pro-inflammatory signaling remodels androgen receptor and NF-kappaB cistrome to reprogram the prostate cancer cell transcriptome. Nucleic Acids Res. 2017, 45, 619-630. [CrossRef]

40. Jin, R.J.; Lho, Y.; Connelly, L.; Wang, Y.; Yu, X.; Saint Jean, L.; Case, T.C.; Ellwood-Yen, K.; Sawyers, C.L.; Bhowmick, N.A.; et al. The nuclear factor-kappaB pathway controls the progression of prostate cancer to androgen-independent growth. Cancer Res. 2008, 68, 6762-6769. [CrossRef]

41. Zeligs, K.P.; Neuman, M.K.; Annunziata, C.M. Molecular Pathways: The Balance between Cancer and the Immune System Challenges the Therapeutic Specificity of Targeting Nuclear Factor-kappaB Signaling for Cancer Treatment. Clin. Cancer Res. 2016, 22, 4302-4308. [CrossRef] [PubMed]

42. Beider, K.; Abraham, M.; Begin, M.; Wald, H.; Weiss, I.D.; Wald, O.; Pikarsky, E.; Abramovitch, R.; Zeira, E.; Galun, E.; et al. Interaction between CXCR4 and CCL20 pathways regulates tumor growth. PLoS ONE 2009, 4, e5125. [CrossRef] [PubMed]

43. You, Z.; Ge, D.; Liu, S.; Zhang, Q.; Borowsky, A.D.; Melamed, J. Interleukin-17 Induces Expression of Chemokines and Cytokines in Prostatic Epithelial Cells but Does Not Stimulate Cell Growth In Vitro. Int. J. Med. Biol. Front. 2012, 18, 629-644. [PubMed]

44. Zhang, Q.; Liu, S.; Parajuli, K.R.; Zhang, W.; Zhang, K.; Mo, Z.; Liu, J.; Chen, Z.; Yang, S.; Wang, A.R.; et al. Interleukin-17 promotes prostate cancer via MMP7-induced epithelial-to-mesenchymal transition. Oncogene 2017, 36, 687-699. [CrossRef] 
45. Pajouh, M.S.; Nagle, R.B.; Breathnach, R.; Finch, J.S.; Brawer, M.K.; Bowden, G.T. Expression of metalloproteinase genes in human prostate cancer. J. Cancer Res. Clin. Oncol. 1991, 117, 144-150. [CrossRef]

46. Knox, J.D.; Wolf, C.; McDaniel, K.; Clark, V.; Loriot, M.; Bowden, G.T.; Nagle, R.B. Matrilysin expression in human prostate carcinoma. Mol. Carcinog. 1996, 15, 57-63. [CrossRef]

47. Egeblad, M.; Werb, Z. New functions for the matrix metalloproteinases in cancer progression. Nat. Rev. Cancer 2002, 2, 161-174. [CrossRef]

48. Powell, W.C.; Fingleton, B.; Wilson, C.L.; Boothby, M.; Matrisian, L.M. The metalloproteinase matrilysin proteolytically generates active soluble Fas ligand and potentiates epithelial cell apoptosis. Curr. Biol. 1999, 9, 1441-1447. [CrossRef]

49. Mitsiades, N.; Yu, W.H.; Poulaki, V.; Tsokos, M.; Stamenkovic, I. Matrix metalloproteinase-7-mediated cleavage of Fas ligand protects tumor cells from chemotherapeutic drug cytotoxicity. Cancer Res. 2001, 61, 577-581.

50. Tung, M.C.; Hsieh, S.C.; Yang, S.F.; Cheng, C.W.; Tsai, R.T.; Wang, S.C.; Huang, M.H.; Hsieh, Y.H. Knockdown of lipocalin-2 suppresses the growth and invasion of prostate cancer cells. Prostate 2013, 73, 1281-1290. [CrossRef]

51. Mahadevan, N.R.; Rodvold, J.; Almanza, G.; Perez, A.F.; Wheeler, M.C.; Zanetti, M. ER stress drives Lipocalin 2 upregulation in prostate cancer cells in an NF-kappaB-dependent manner. BMC Cancer 2011, 11, 229. [CrossRef] [PubMed]

52. Somasundar, P.; Yu, A.K.; Vona-Davis, L.; McFadden, D.W. Differential effects of leptin on cancer in vitro. J. Surg. Res. 2003, 113, 50-55. [CrossRef]

53. Somasundar, P.; Frankenberry, K.A.; Skinner, H.; Vedula, G.; McFadden, D.W.; Riggs, D.; Jackson, B.; Vangilder, R.; Hileman, S.M.; Vona-Davis, L.C. Prostate cancer cell proliferation is influenced by leptin. J. Surg. Res. 2004, 118, 71-82. [CrossRef] [PubMed]

54. Hoda, M.R.; Popken, G. Mitogenic and anti-apoptotic actions of adipocyte-derived hormone leptin in prostate cancer cells. BJU Int. 2008, 102, 383-388. [CrossRef] [PubMed]

55. Tanaka, T.; Umesaki, N. Leptin regulates the proliferation and apoptosis of human endometrial epithelial cells. Int. J. Mol. Med. 2008, 22, 683-689. [CrossRef] [PubMed]

56. Qian, H.; Azain, M.J.; Compton, M.M.; Hartzell, D.L.; Hausman, G.J.; Baile, C.A. Brain administration of leptin causes deletion of adipocytes by apoptosis. Endocrinology 1998, 139, 791-794. [CrossRef] [PubMed]

57. Kim, G.S.; Hong, J.S.; Kim, S.W.; Koh, J.M.; An, C.S.; Choi, J.Y.; Cheng, S.L. Leptin induces apoptosis via ERK/cPLA2/cytochrome c pathway in human bone marrow stromal cells. J. Biol. Chem. 2003, 278, 21920-21929. [CrossRef]

58. Zhu, M.L.; Kyprianou, N. Androgen receptor and growth factor signaling cross-talk in prostate cancer cells. Endocr. Relat. Cancer 2008, 15, 841-849. [CrossRef]

59. Russell, P.J.; Bennett, S.; Stricker, P. Growth factor involvement in progression of prostate cancer. Clin. Chem. 1998, 44, 705-723.

60. Wu, Y.; Zhao, W.; Zhao, J.; Pan, J.; Wu, Q.; Zhang, Y.; Bauman, W.A.; Cardozo, C.P. Identification of androgen response elements in the insulin-like growth factor I upstream promoter. Endocrinology 2007, 148, 2984-2993. [CrossRef]

61. Heinlein, C.A.; Chang, C. Androgen receptor in prostate cancer. Endocr. Rev. 2004, 25, 276-308. [CrossRef] [PubMed]

62. Jin, L.; Zhang, S.; Burguera, B.G.; Couce, M.E.; Osamura, R.Y.; Kulig, E.; Lloyd, R.V. Leptin and leptin receptor expression in rat and mouse pituitary cells. Endocrinology 2000, 141, 333-339. [CrossRef] [PubMed]

63. Kosior-Korzecka, U.; Bobowiec, R. Leptin effect on nitric oxide and GnRH-induced FSH secretion from ovine pituitary cells in vitro. J. Physiol. Pharmacol. 2006, 57, 637-647. [PubMed]

64. Weil, C.; Le Bail, P.Y.; Sabin, N.; Le Gac, F. In vitro action of leptin on FSH and LH production in rainbow trout (Onchorynchus mykiss) at different stages of the sexual cycle. Gen. Comp. Endocrinol. 2003, 130, 2-12. [CrossRef]

65. Chen, C.; Roh, S.G.; Nie, G.Y.; Loneragan, K.; Xu, R.W.; Ruan, M.; Clarke, L.J.; Goding, J.W.; Gertler, A. The in vitro effect of leptin on growth hormone secretion from primary cultured ovine somatotrophs. Endocrine 2001, 14, 73-78. [CrossRef] 
66. Melen-Mucha, G.; Lawnicka, H. Leptin promotes the growth of Colon 38 cancer cells and interferes with the cytotoxic effect of fluorouracil in vitro. Endokrynol. Pol. 2007, 58, 2-6. [PubMed]

67. Szyszka, M.; Paschke, L.; Tyczewska, M.; Rucinski, M.; Grabowska, P.; Malendowicz, L.K. Lack of expression of preproorexin and orexin receptors genes in human normal and prostate cancer cell lines. Folia Histochem. Cytobiol. 2015, 53, 333-341. [CrossRef] [PubMed]

68. Paschke, L.; Zemleduch, T.; Rucinski, M.; Ziolkowska, A.; Szyszka, M.; Malendowicz, L.K. Adiponectin and adiponectin receptor system in the rat adrenal gland: Ontogenetic and physiologic regulation, and its involvement in regulating adrenocortical growth and steroidogenesis. Peptides 2010,31, 1715-1724. [CrossRef]

69. Jopek, K.; Tyczewska, M.; Celichowski, P.; Malendowicz, L.K.; Rucinski, M. Transcriptome Profile in Unilateral Adrenalectomy-Induced Compensatory Adrenal Growth in the Rat. Int. J. Mol. Sci. 2018, 19, 1111. [CrossRef]

70. Jopek, K.; Celichowski, P.; Szyszka, M.; Tyczewska, M.; Milecka, P.; Malendowicz, L.K.; Rucinski, M. Transcriptome Profile of Rat Adrenal Evoked by Gonadectomy and Testosterone or Estradiol Replacement. Front. Endocrinol. (Lausanne) 2017, 8, 26. [CrossRef]

71. Trejter, M.; Hochol, A.; Tyczewska, M.; Ziolkowska, A.; Jopek, K.; Szyszka, M.; Malendowicz, L.K.; Rucinski, M. Visinin-like peptide 1 in adrenal gland of the rat. Gene expression and its hormonal control. Peptides 2015, 63, 22-29. [CrossRef] [PubMed]

72. Piotrowska-Kempisty, H.; Rucinski, M.; Borys, S.; Kucinska, M.; Kaczmarek, M.; Zawierucha, P.; Wierzchowski, M.; Lazewski, D.; Murias, M.; Jodynis-Liebert, J. 3'-hydroxy-3,4,5,4'-tetramethoxystilbene, the metabolite of resveratrol analogue DMU-212, inhibits ovarian cancer cell growth in vitro and in a mice xenograft model. Sci. Rep. 2016, 6, 32627. [CrossRef] [PubMed]

73. Gautier, L.; Cope, L.; Bolstad, B.M.; Irizarry, R.A. Affy-analysis of Affymetrix GeneChip data at the probe level. Bioinformatics 2004, 20, 307-315. [CrossRef] [PubMed]

74. Carvalho, B.S.; Irizarry, R.A. A framework for oligonucleotide microarray preprocessing. Bioinformatics 2010, 26, 2363-2367. [CrossRef]

75. Ritchie, M.E.; Phipson, B.; Wu, D.; Hu, Y.; Law, C.W.; Shi, W.; Smyth, G.K. limma powers differential expression analyses for RNA-sequencing and microarray studies. Nucleic Acids Res. 2015, 43, e47. [CrossRef]

76. Dennis, G., Jr.; Sherman, B.T.; Hosack, D.A.; Yang, J.; Gao, W.; Lane, H.C.; Lempicki, R.A. DAVID: Database for Annotation, Visualization, and Integrated Discovery. Genome Biol. 2003, 4, P3. [CrossRef]

77. Fresno, C.; Fernandez, E.A. RDAVIDWebService: A versatile R interface to DAVID. Bioinformatics 2013, 29, 2810-2811. [CrossRef]

78. Benjamini, Y.; Cohen, R. Weighted false discovery rate controlling procedures for clinical trials. Biostatistics 2017, 18, 91-104. [CrossRef]

79. Walter, W.; Sanchez-Cabo, F.; Ricote, M. GOplot: An R package for visually combining expression data with functional analysis. Bioinformatics 2015, 31, 2912-2914. [CrossRef]

80. Damian, D.; Gorfine, M. Statistical concerns about the GSEA procedure. Nat. Genet. 2004, 36, 663. [CrossRef]

81. Sergushichev, A. An algorithm for fast preranked gene set enrichment analysis using cumulative statistic calculation. BioRxiv 2016. [CrossRef]

82. Liberzon, A.; Birger, C.; Thorvaldsdottir, H.; Ghandi, M.; Mesirov, J.P.; Tamayo, P. The Molecular Signatures Database (MSigDB) hallmark gene set collection. Cell Syst. 2015, 1, 417-425. [CrossRef] [PubMed]

83. Subramanian, A.; Tamayo, P.; Mootha, V.K.; Mukherjee, S.; Ebert, B.L.; Gillette, M.A.; Paulovich, A.; Pomeroy, S.L.; Golub, T.R.; Lander, E.S.; et al. Gene set enrichment analysis: A knowledge-based approach for interpreting genome-wide expression profiles. Proc. Natl. Acad. Sci. USA 2005, 102, 15545-15550. [CrossRef] [PubMed]

84. Luo, W.; Brouwer, C. Pathview: An R/Bioconductor package for pathway-based data integration and visualization. Bioinformatics 2013, 29, 1830-1831. [CrossRef]

85. Paschke, L.; Jopek, K.; Szyszka, M.; Tyczewska, M.; Ziolkowska, A.; Rucinski, M.; Malendowicz, L.K. ZFP91: A Noncanonical NF-kappaB Signaling Pathway Regulator with Oncogenic Properties Is Overexpressed in Prostate Cancer. BioMed. Res. Int. 2016, 2016, 6963582. [CrossRef]

86. Ritz, C.; Baty, F.; Streibig, J.C.; Gerhard, D. Dose-Response Analysis Using R. PLoS ONE 2015, 10 , e0146021. [CrossRef] 
87. Cancer Genome Atlas Research Network. The Molecular Taxonomy of Primary Prostate Cancer. Cell 2015, 163, 1011-1025. [CrossRef]

88. Deng, M.; Bragelmann, J.; Kryukov, I.; Saraiva-Agostinho, N.; Perner, S. FirebrowseR: An R client to the Broad Institute's Firehose Pipeline. Database (Oxford) 2017, 2017, baw160. [CrossRef]

(C) 2019 by the authors. Licensee MDPI, Basel, Switzerland. This article is an open access article distributed under the terms and conditions of the Creative Commons Attribution (CC BY) license (http://creativecommons.org/licenses/by/4.0/). 